\title{
فاعلية برنامج قائم علي الفهم القرائي لتتمية اللغة التعبيرية للأطفال ذوي صعوبات التعلم
}

إعداد

الباحث / رضا عبد الفتاح حسن المقدم'

أ.م.د / أحمد عبد الرحيم العمري

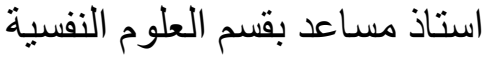

كلية التربية للطفولة المبكرة

جامعة القاهرة
أ.د / شحاتة سليمان شحمد سليمان

استاذ الصحة النفسية

كلية التربية للطفولة المبكرة

جامعة القاهرة

المستخلص:

قياس فاعلية برنامج قائم علي الفهم القرائي لتنمية اللغة التعبيرية لدي الأطفال ذوي صعوبات التعلم. هدف البحث الحالي إلي قياس فاعلية برنامج قائم علي الفهم القرائي لتنمية اللغة التعبيرية لدي الأطية التفال ذوي صعوبات التعلم، وقياس مدي استمراريته.اعتمد البحث الحالي على المنهج شبه التجريبي ذو التصميم التجريبي

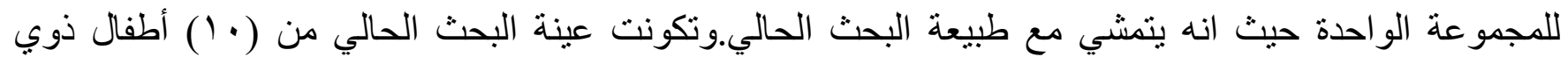

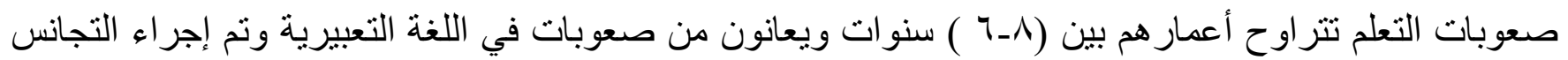

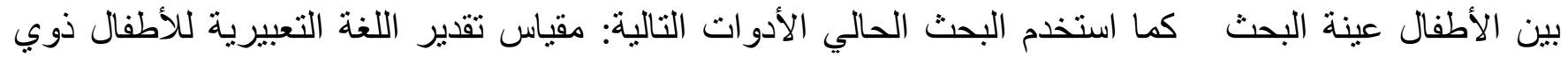

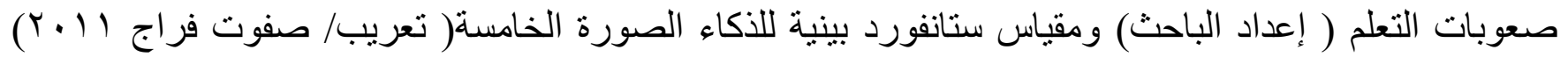

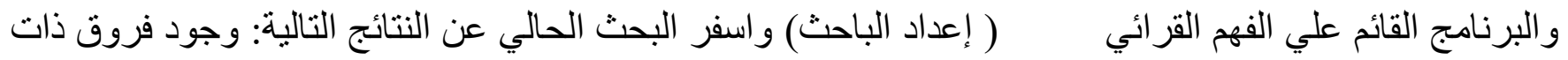
دلالة احصائية بين منوسطي رثب درجات الأطفال من حيث تنمية اللغة التعبيرية في القياسين القبلي و البعدي على ولى ولى

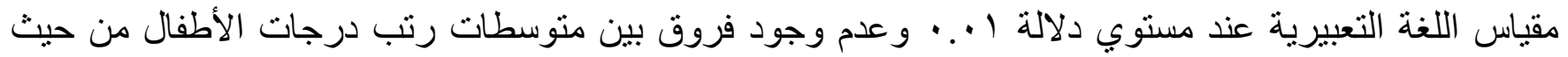
اللغة التعبيرية في القياسين البعدي و التتبعي للبرنامج على مقياس اللغة التعبيرية عند أبي مستوي دلالة بعد مرور شهر من القياس البعدي. الكلمات الدالة : صعوبات التعلم - الفهم القر ائيـ اللغة التعبيرية . 


\begin{abstract}
The Aim of present research is to measure the effectiveness of a program based on reading comprehension of the development of expressive language in children with learning difficulties, and measure the extent of its continuity. The participants of the research consisted of (10) Children with Learning Difficulties. whose ages ranged from (6 - 8 years) with Expressive Language Difficulties. Harmonization among Children was done. The present research used the following tools: Scale of Expression Language for Children with Learning Disabilities. (Prepared by the Researcher) Stanford-Binet intelligence Scale Fifth Edition (Arabization / Safwat Farag 2011) and the program based on reading comprehension (Prepared by the Researcher). The result revealed There are statistically significant differences between the mean grades of children in terms of expressive language development in the pre and post measurements on the expressive language scale at the level of 0.01 and the absence of differences between the mean grades of children in terms of expressive language in the two measurements The program is tracked on the expressive language scale at any significant level after one month of telemetry.
\end{abstract}

Key words: Learning Disabilities - Reading Comprehension - Expressive Language. 


\section{مقدمة البحث}

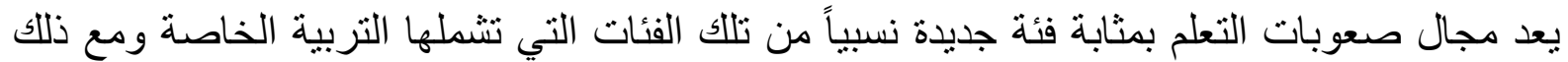

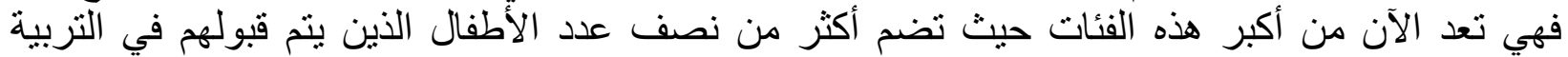

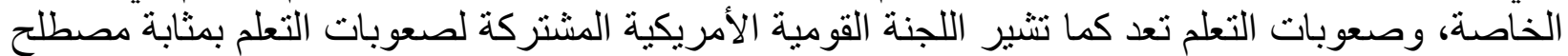

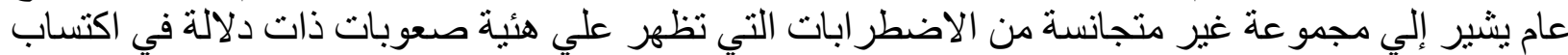
و استخدام القدرة علي الاستماع، أو التحدث، أو القراعة ماءة، أو الكتابة .

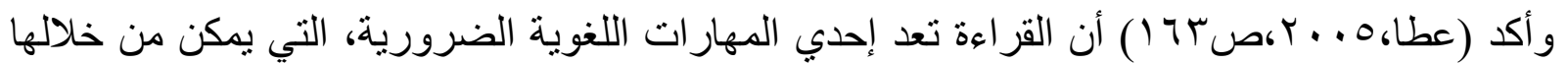
تزويد الطفل ذوي صعوبات التعلم بما يحتاج إليه من معلومات؛ لذا فهي تمثل جوهر هر العملية التعليمية، كما تعد القراءة من أهم المهار ات التي يجب أن يكتسبها الطفل، ويعمل علي تنميتها، مثل: السرعة القرائية،

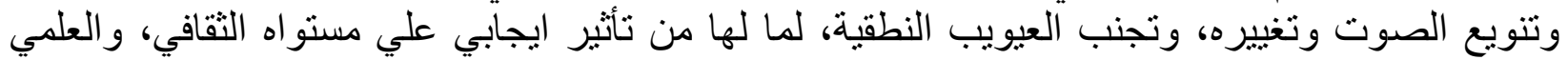

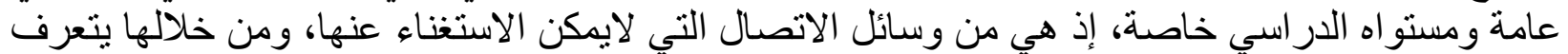

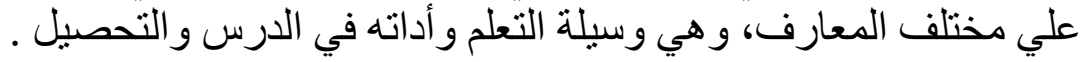

ويعتبر الفهم هو المهارة الثانية من مهار ات القراعة، و الهدف من كل قر اعة فهم المعني، والخطوة الأولي

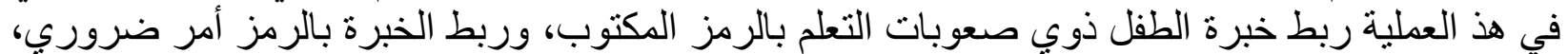

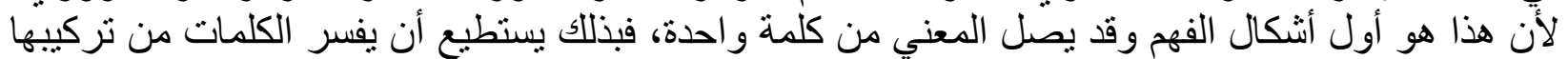

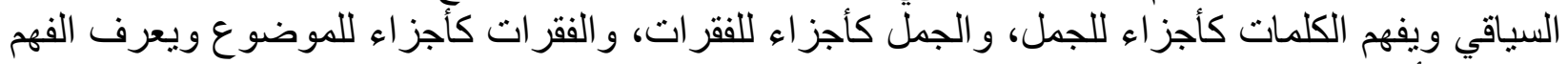

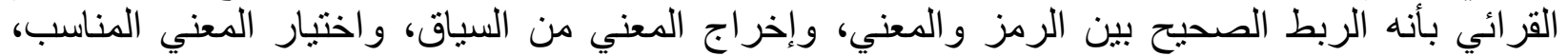

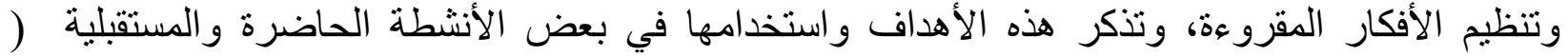

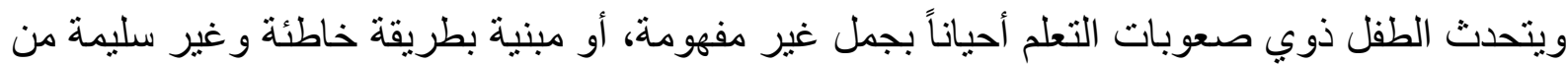
ناحية التركيب. فهؤلاء الأطفال لايهم صعوبة واضحة في التعبير اللغوي الثفوي. إذ نجدهم يتعثرون في مئي اختيار الكلمات المناسبة، ويكررون الكثير من الكلمات، ويستخدمون جملاً متقطعة، و وأحياناً دون معنى في عندما يطلب منهم التحدث عن تجربة معينة، أو استرجاع أحداث قصة قد سمعو ها سابقاً. وقد تطول قصتهم دون

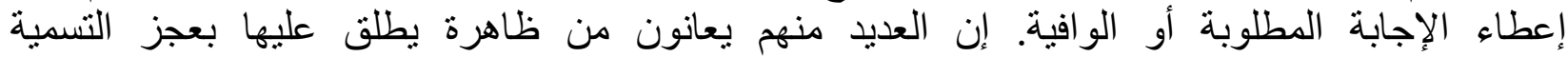
أي صعوبة في استخراج الكلمات أو إعطاء الأسماء أو الاصطلاحات الصحيحة للمعاني (Dysnomia)

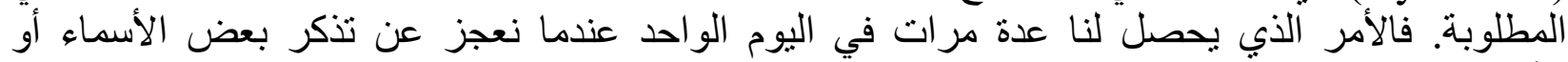

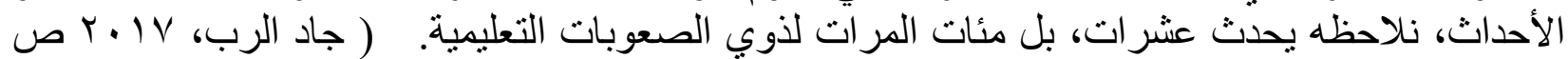

أكد) أن صعوبات اللغة و الكلام من أهم الصعوبات التي يعاني منها الأطفال ذوي صعوبات التعلم، حيث تظهر في اللغة بشقيها الاستقبالية والتعبيرية (Henry,2015:p140) فقد أوضح اهن

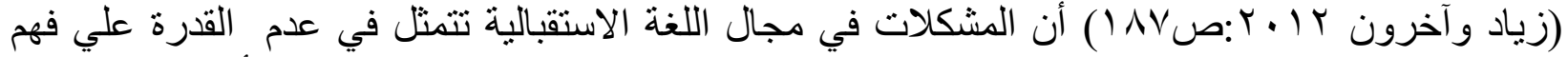

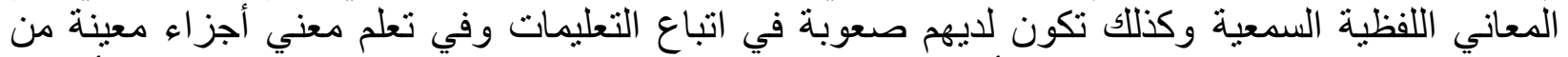

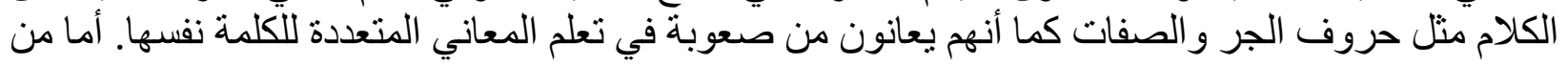

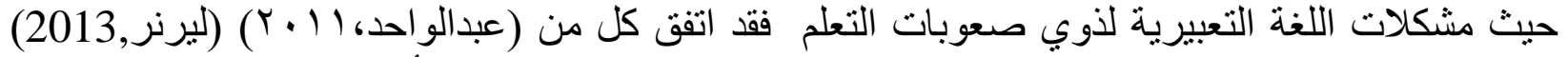
(Andrea,2013) لدي ذوي صعوبات التعلم تتضح من خلال وقوعهم في أخطاء من ناحية التركيب النحوي حيث لايكونون 
قادرين علي التعبير عن المواقف المعروضة أمامهم بجمل واضحة وسليمة من ناحية التركيب اللغوي فقد

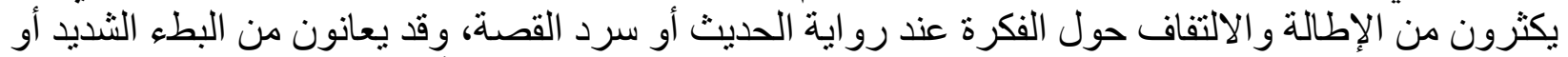

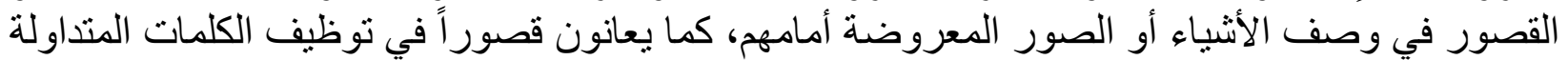

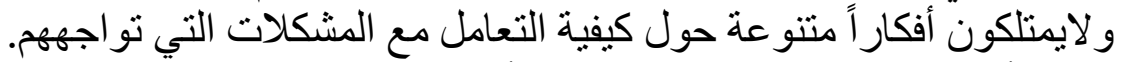

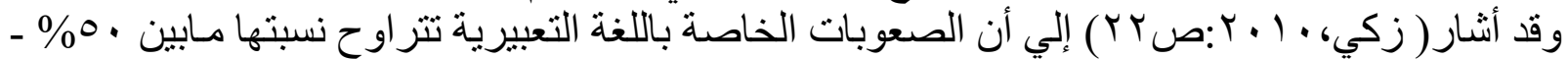

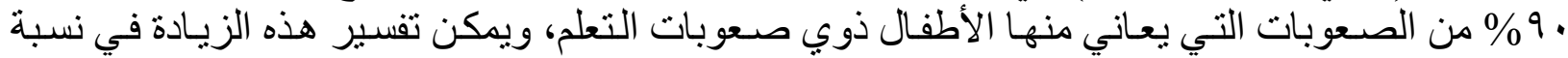

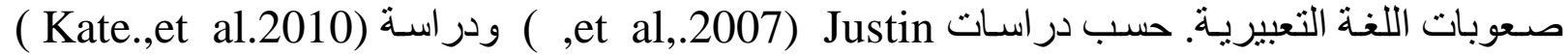
و التي ذكرت وجود علاقة وثيقة بين الفهم القرائي و الضـف في في مستوي اللغـة (Jessie Ricketts,2011)

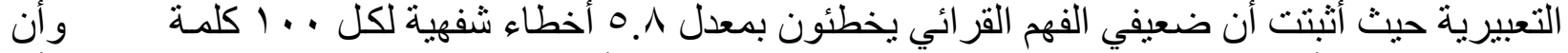

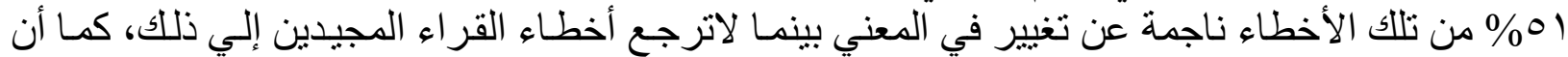

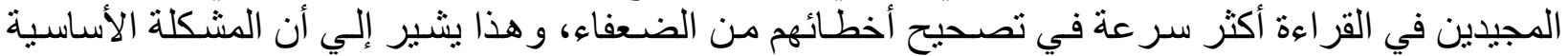

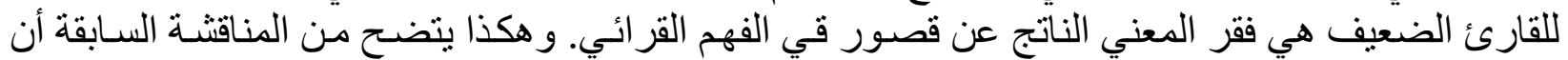

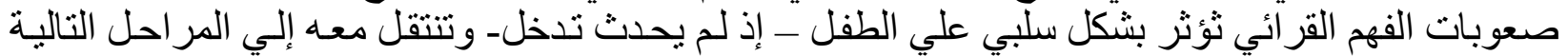

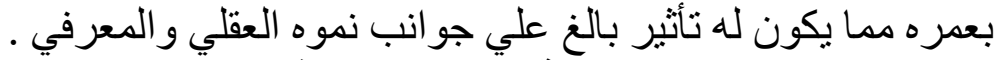

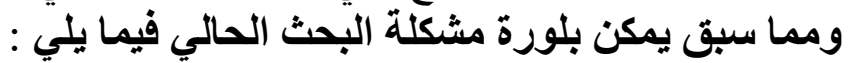

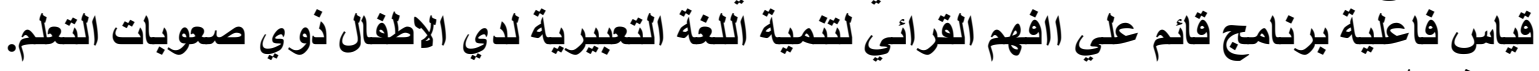

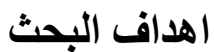

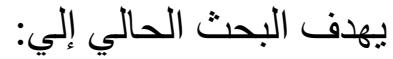

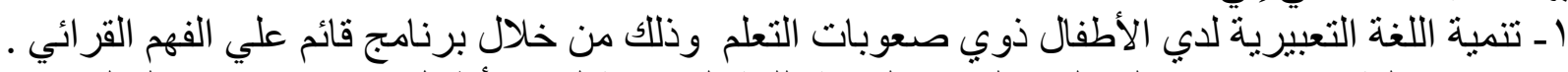

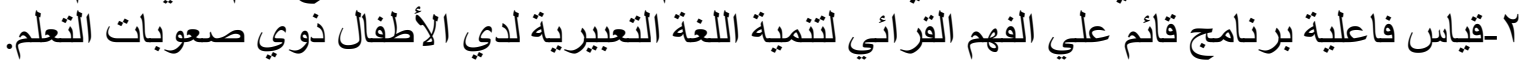

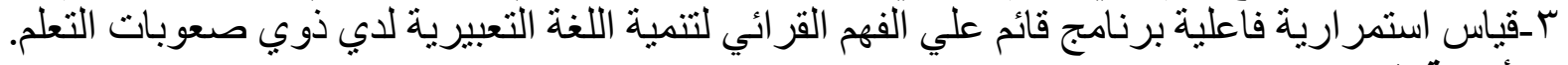

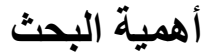

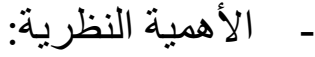
الاسهام النظري من حيث إثراء المعلومات حول صعوبات التعلم وتأثثر اتها السلبية على جوانب النمو

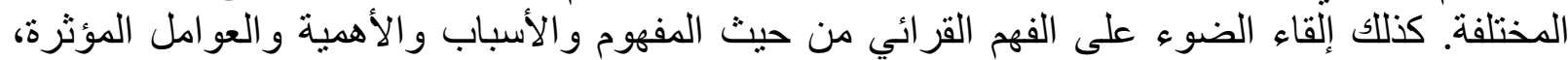

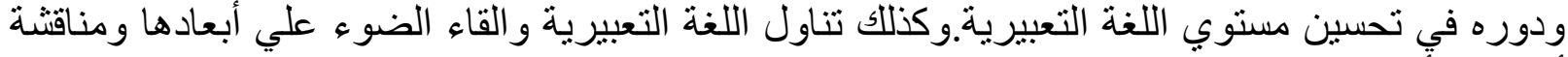
أهميتها لأُطفال هذه الفئة وكذلك تبني النظريات العلمية التي تسهم في تنمية اللغة التعبيرية باستخدام البر امج التهاء

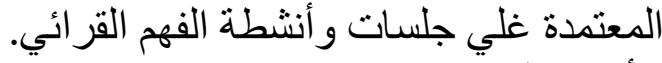

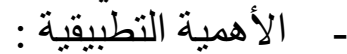

يساهم البحث الحالي في تصميم برنامج قائم علي الفهم القرائي لتنمية اللغة التعبيرية وكذللك يسهم في

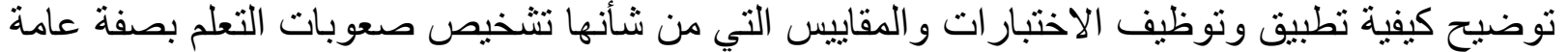

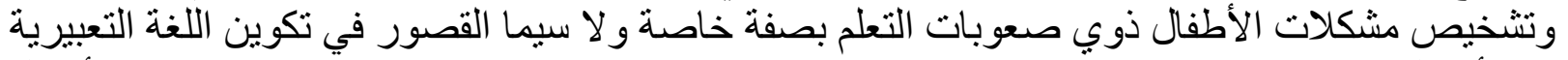

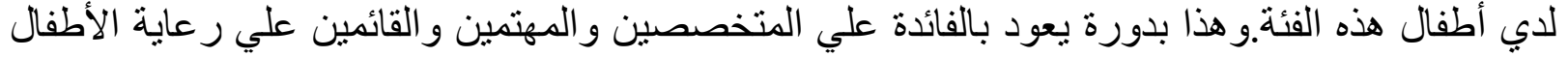

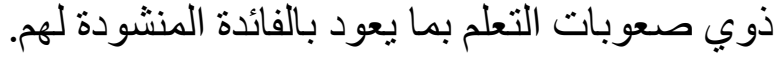

مصطلحات البحث ا - معوبات التعلم

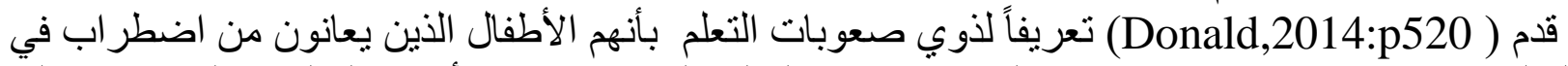

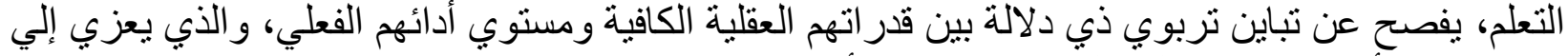

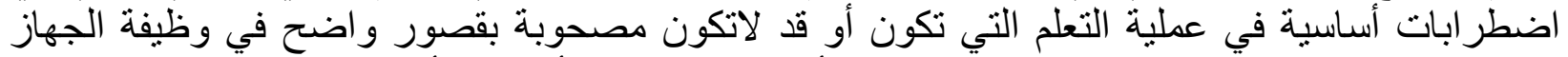
العصبي المركزي، وليست ناتجة عن تخلف عقلي، أو حرمان نربوي أو ثقافي أو اضطر اب أنفعالي شديد. 
ويعرف الباحث مفهوم صعوبات التعلم اجر ائياً بأنه " مفهوم يثير إلي مجموعة غير فئر متجانسة من الأطفال

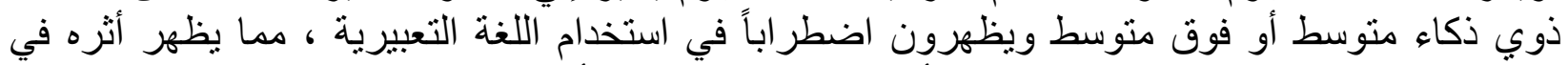
انخفاض تحصيلهم الدراسي في المجلات الأكاديمية ـ مع استثناء الأطفال ذور الاعبة العاقات الحسية سواء كانت

$$
\text { بـ - الفهم القرائي }
$$

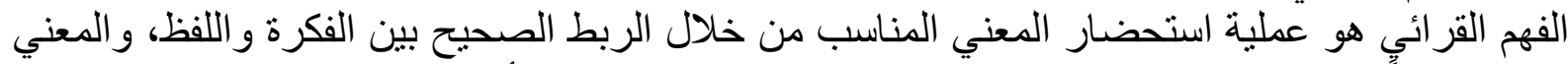

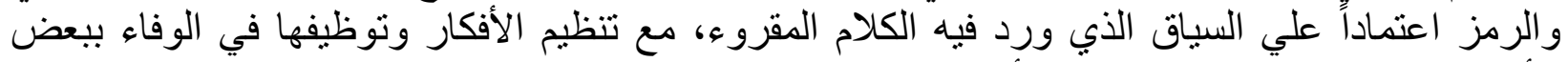

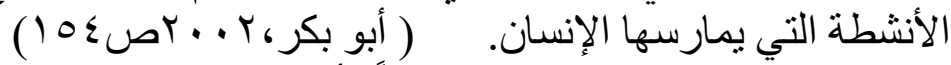

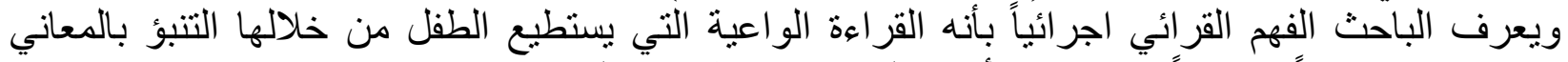

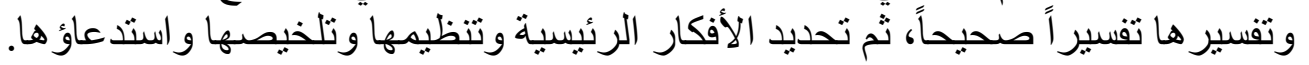

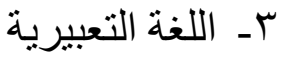

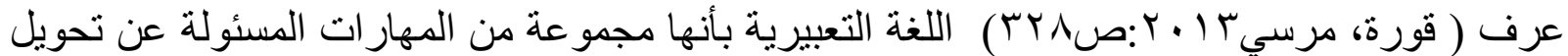

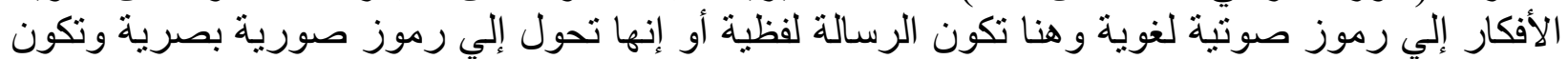

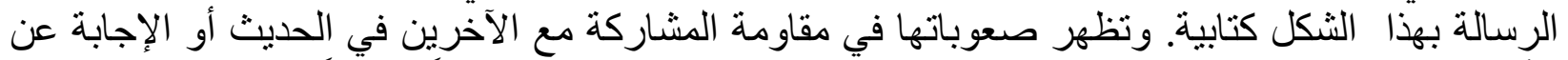

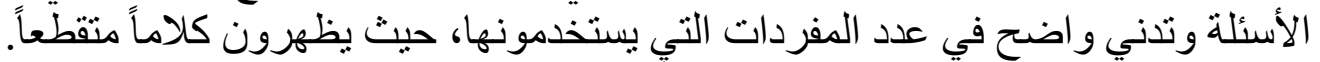

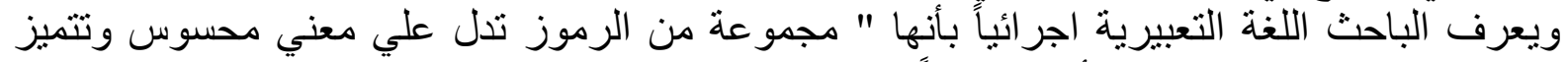

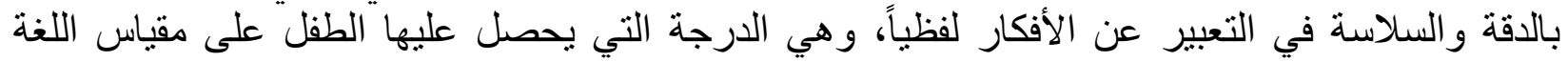

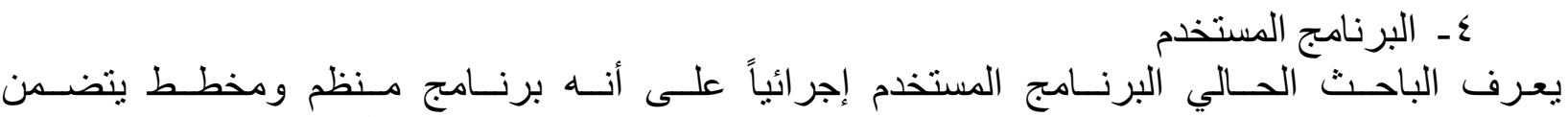

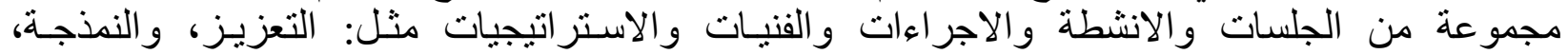

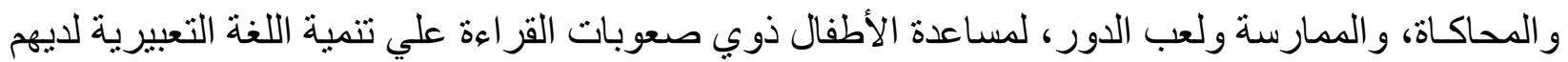

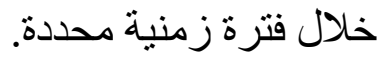
الإطار النظري للبحث

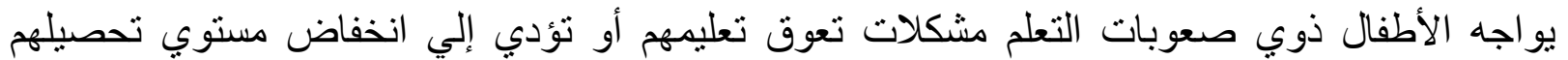

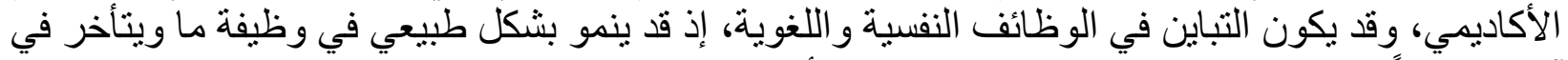

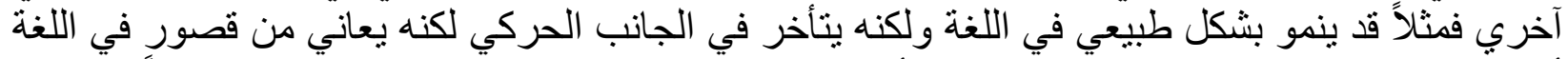

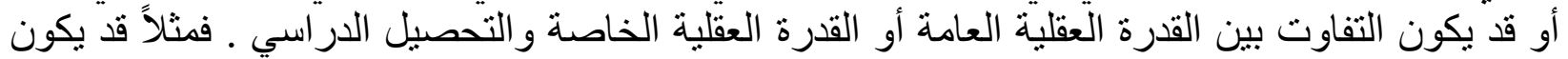

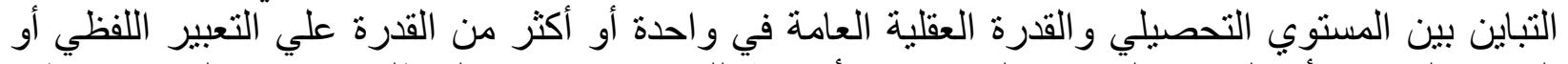

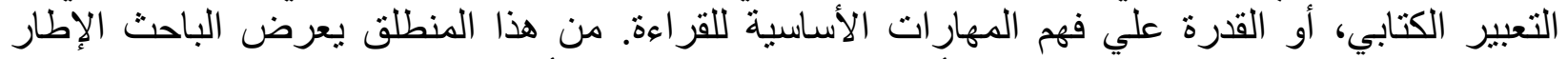

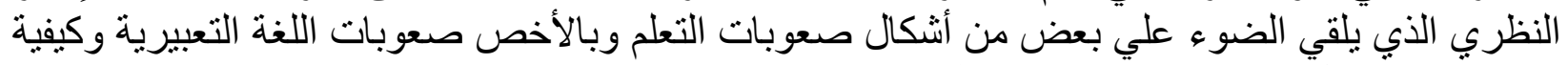

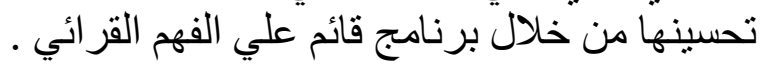




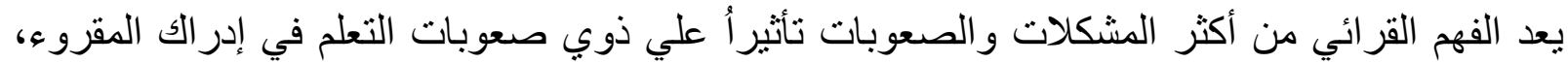

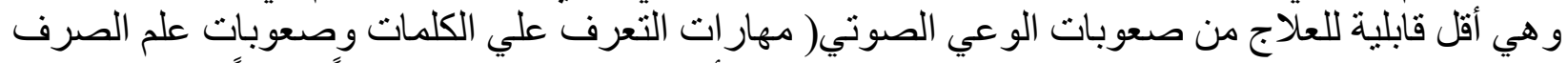

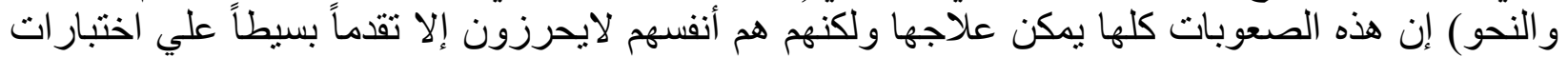

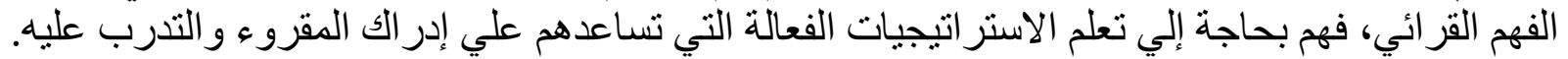

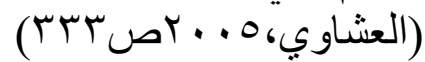

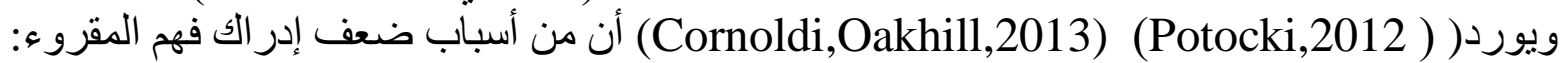

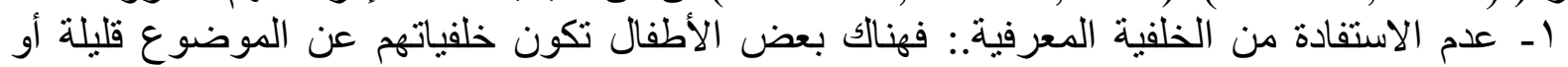

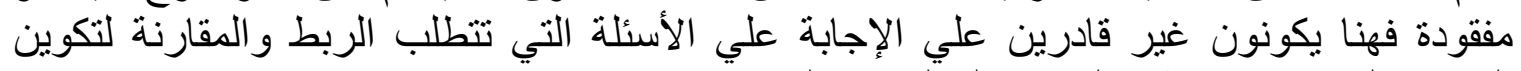

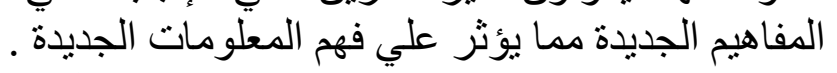

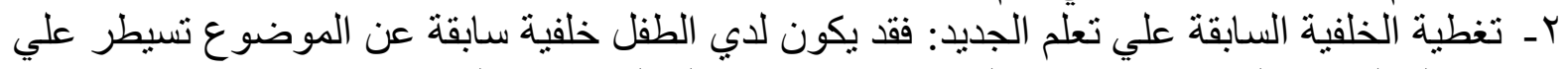

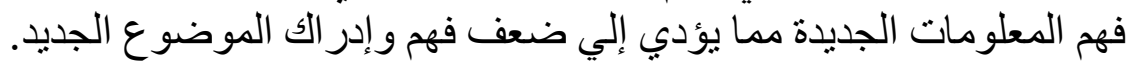

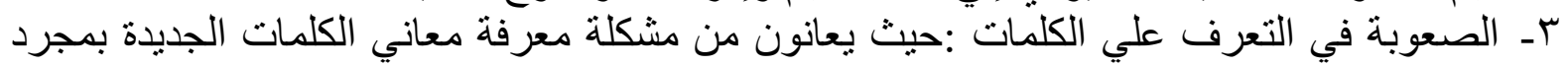
النظرة السريعة إليها.

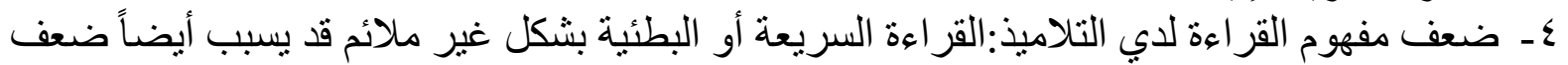

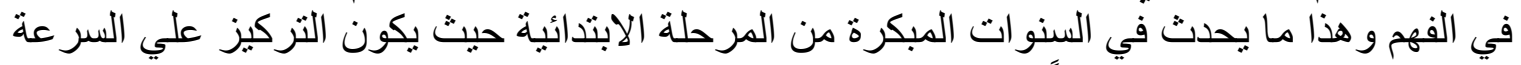

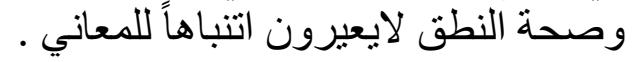

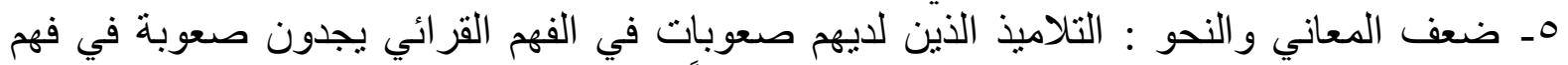

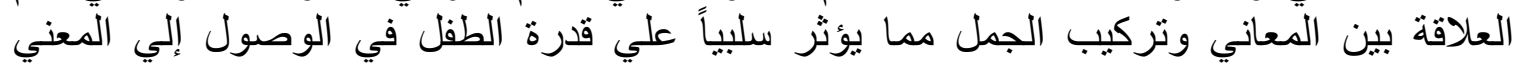

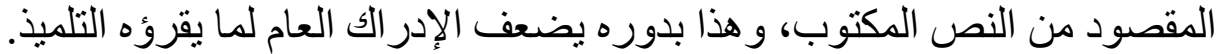

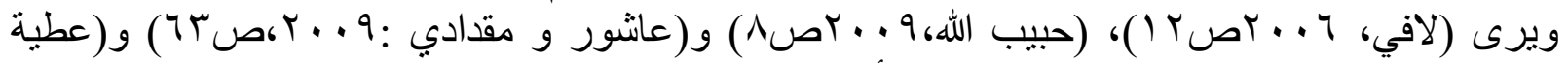

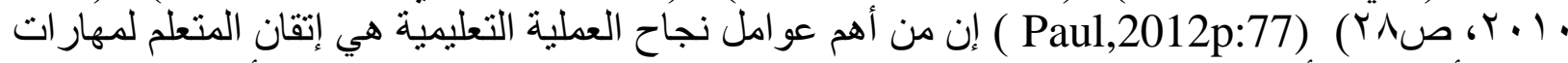

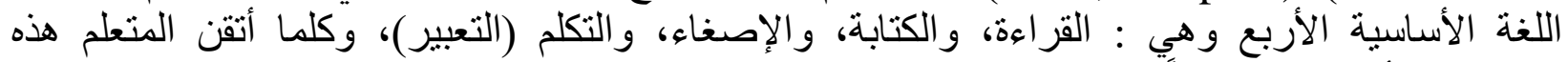

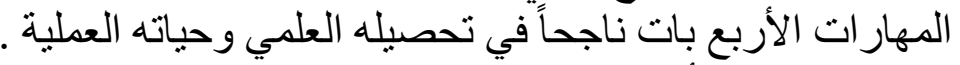

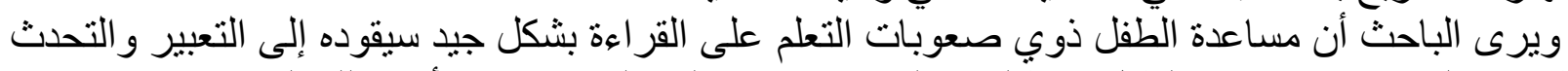

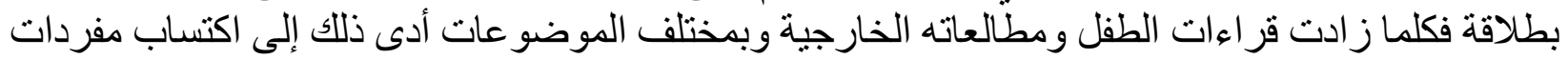

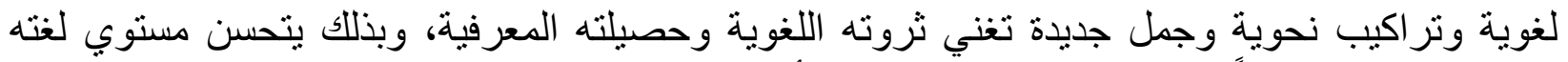

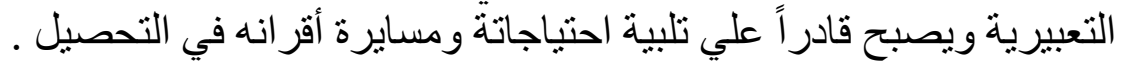

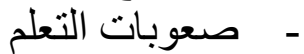

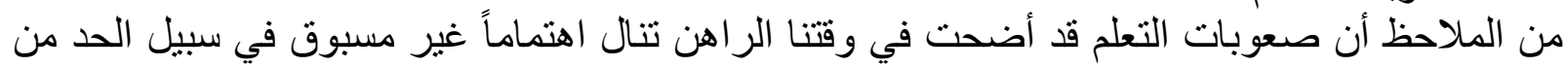

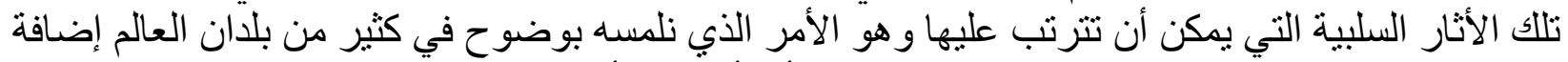

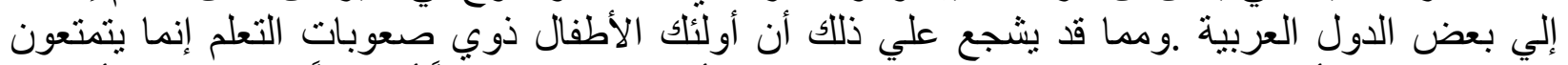

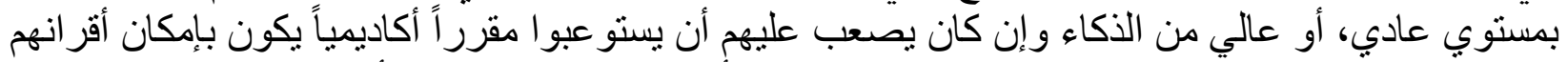

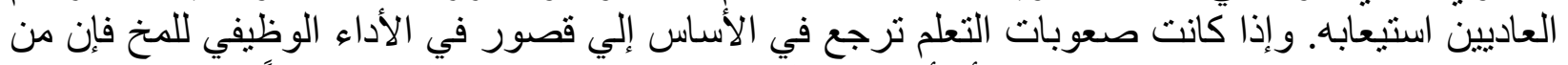

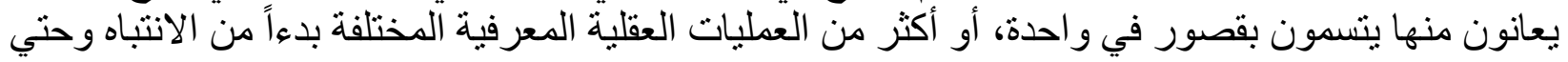

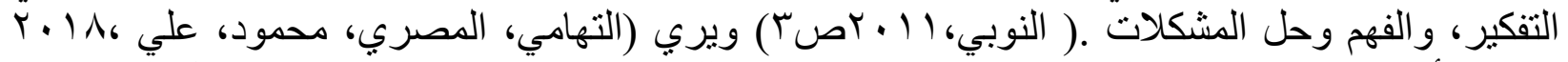

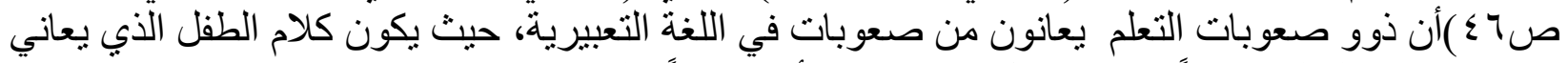

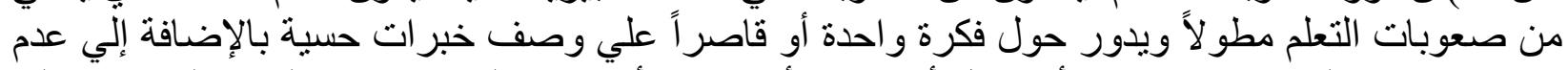

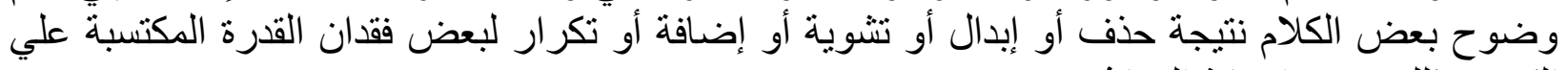
الكلام وذللك بسبب إصنابة الدماغ. نوخ. 


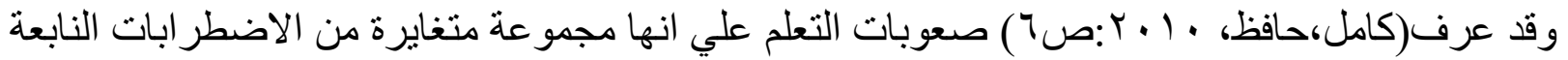

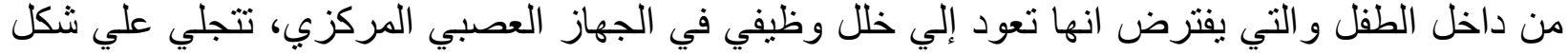

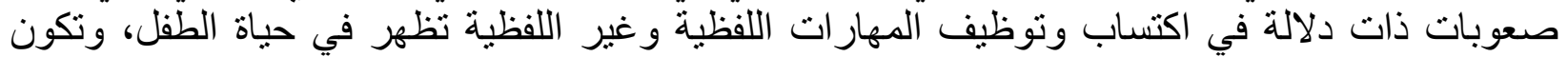

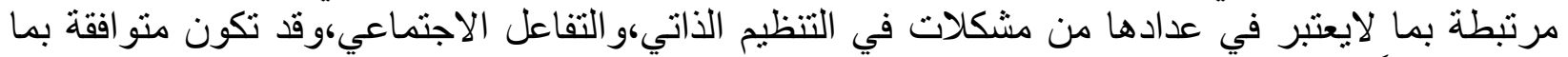

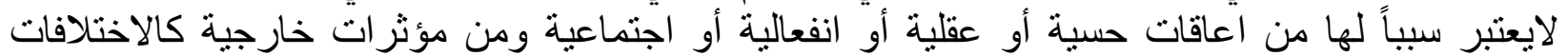
الثقافية أو التعليم غير الملائم مع تمتع هؤ لاء الأطفال بذكاء منوسط أو ألغ فوق المنوسط.

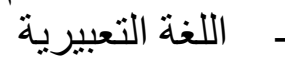

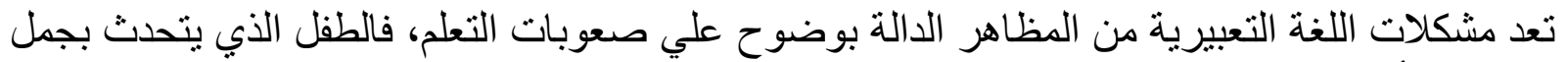

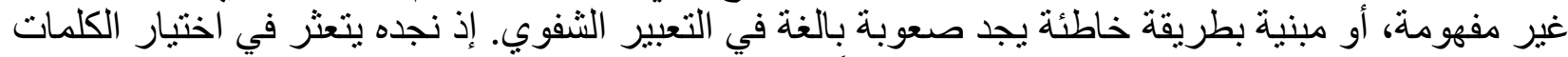

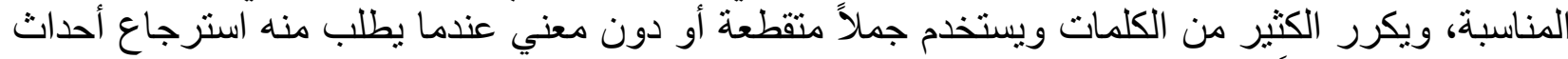

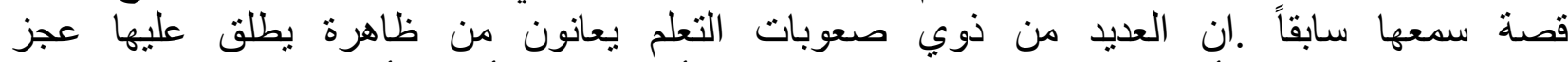

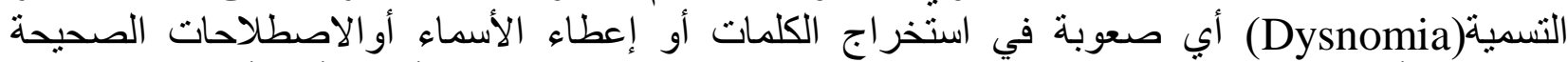

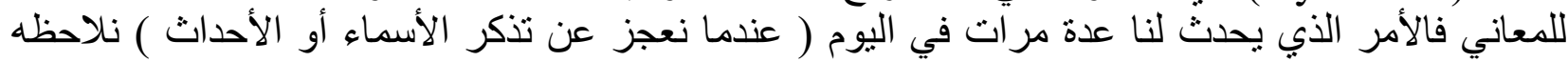

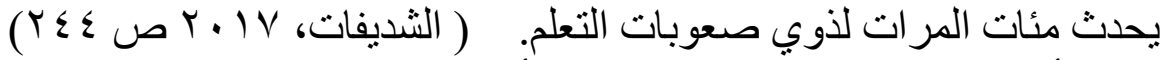

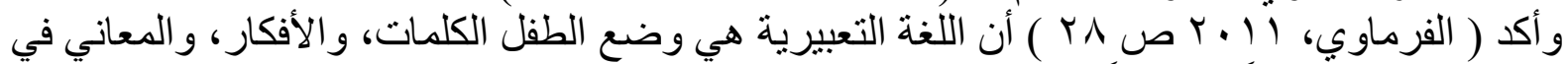

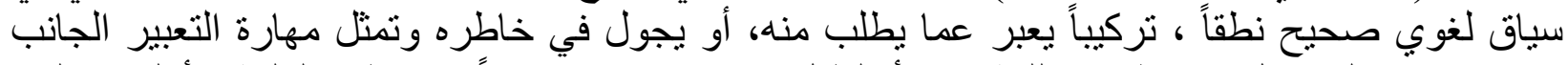

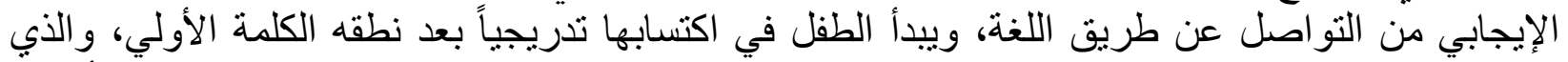

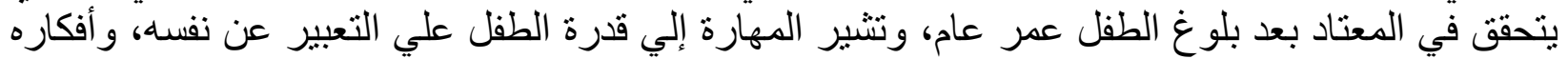

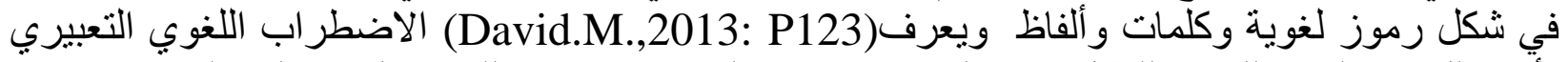

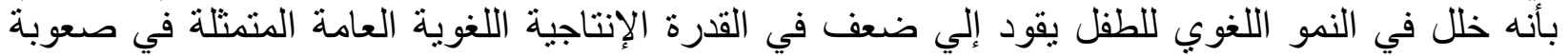

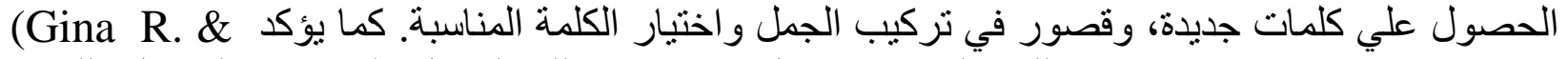

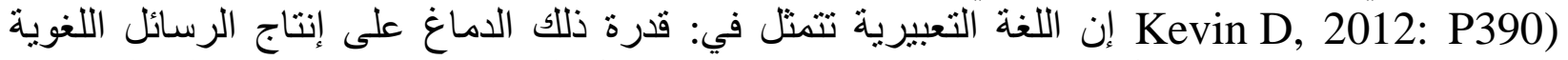

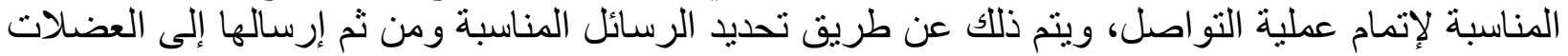

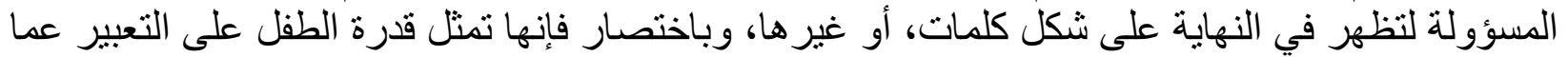

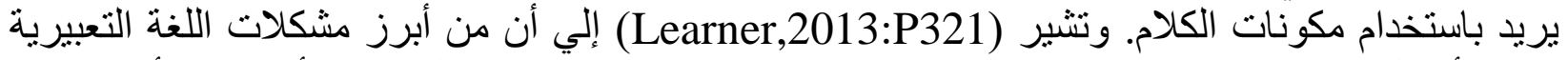

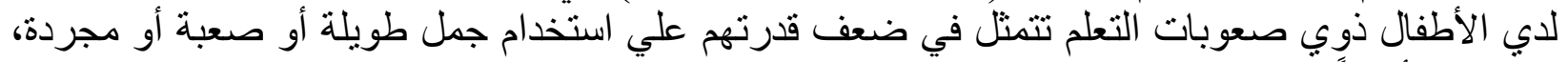

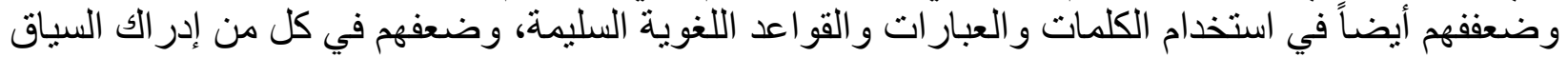

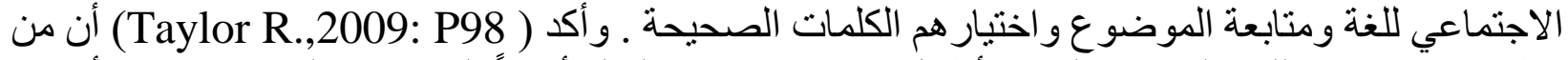

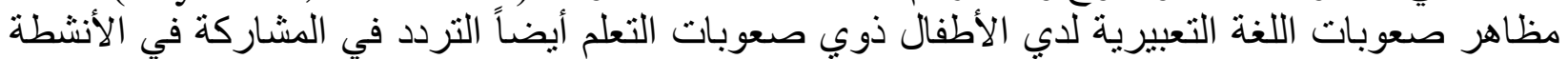

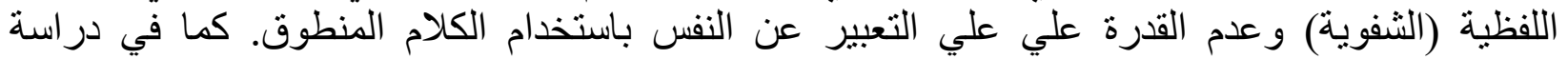

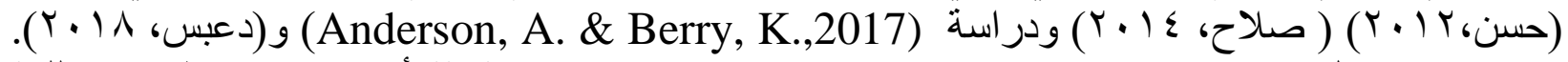

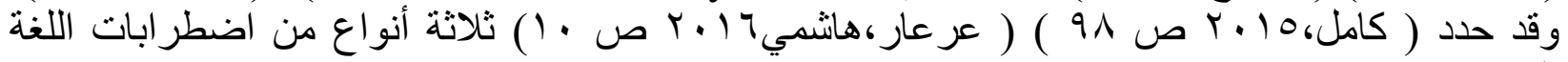
التعبيرية : والد

1 - اضطر ابات مرتبطة بالتكوين

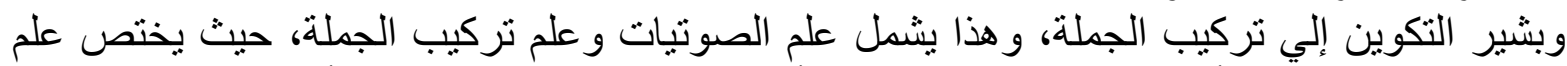
الصوتيات Phonology بأصغر وحدة في اللغة وهي أصوات الكئ الكلام Phonemes . أما علم تركيب الكلمة

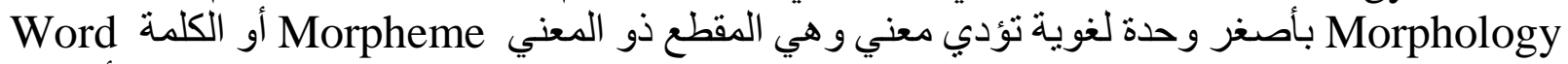

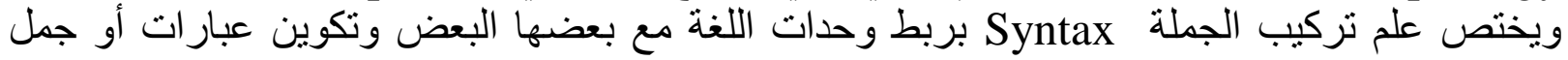
وتظهر المشكلات المتعلقة بعلم الصوتيات و علم تركيب الكلمة وعلم تركيب الجملة ، عندما يكون الطفل غير 
قادر علي التمييز بين الأصوات أو الكلمات أو الجمل الصحيحة لغوياً من الجمل غير الصحيحة أو عندما

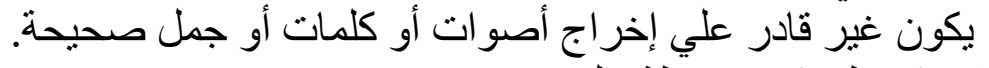

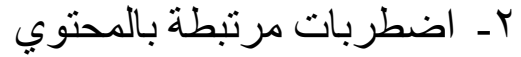

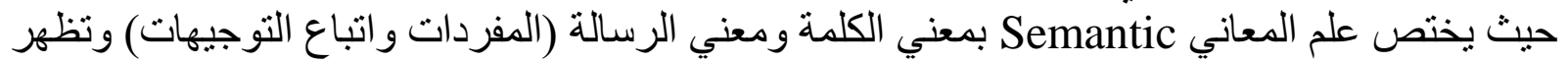

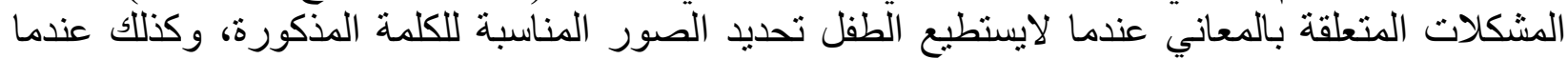

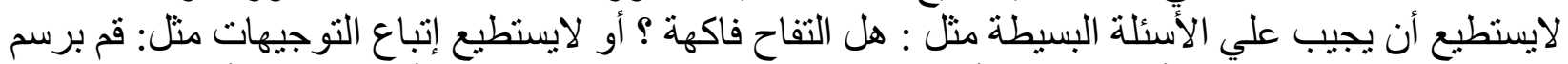

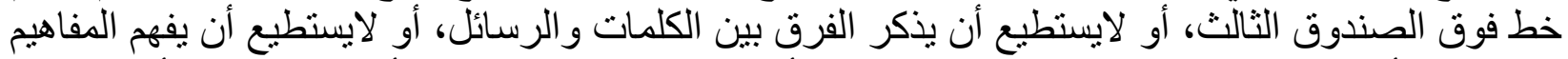

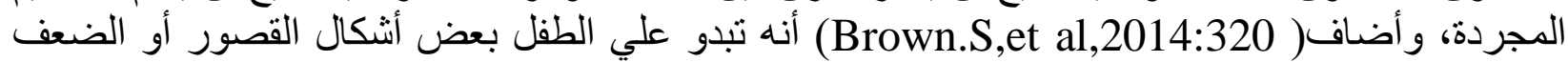

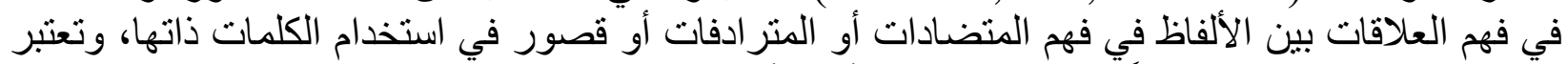

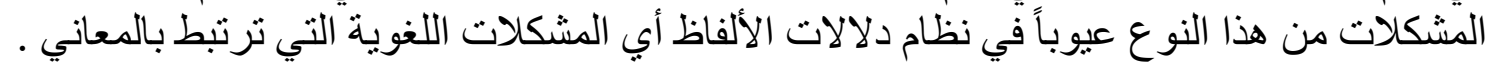

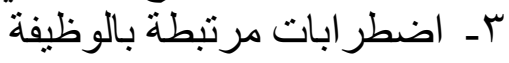

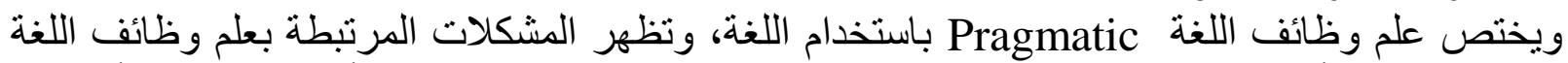

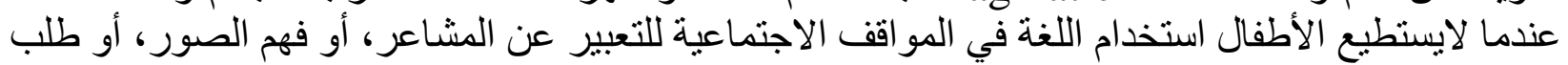

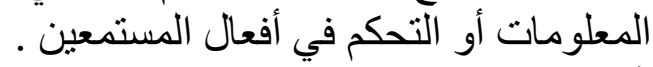
فروض البحث البـ في ضوء الإطار النظري للبحث، ونتائج الدراسات السابقة تم صياغة الفروض التالية للبحث الحالي وهي ا ـ توجد فروق ذات دلالة إحصائية بين منوسطي رتب درجات اطفال العينة ذوي صعوبات اللغة التعبي التبيرية بالمجموعة التجرييية في القياسين القبلي والبعدي لتطبيق التئية البرنامج القائم علي الفهم القرائي من حيث مستوي اللغة التعبيرية في اتجاه القياس البعدي.

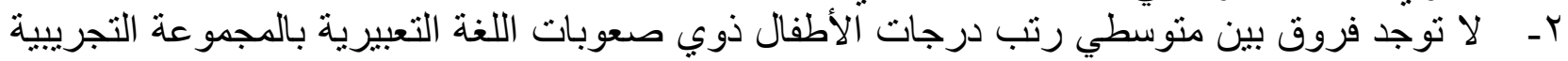

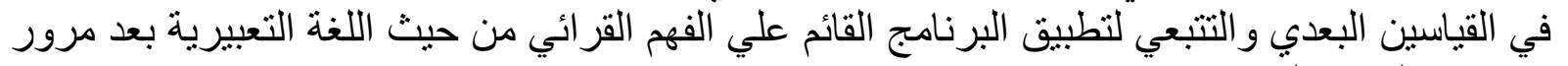
شهر من القياس البعدي.

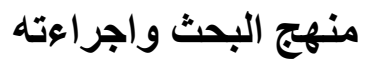

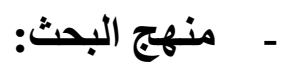

اعتمد البحث الحالي على المنهج شبه التجريبي ذو التصميم التجريبي للمجمو عة الواحدة حيث انه يتمشي مع طبيعة البحث الحالي.

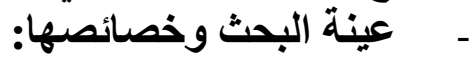

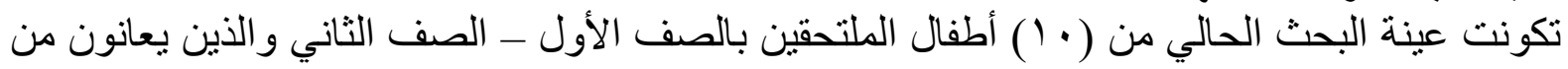

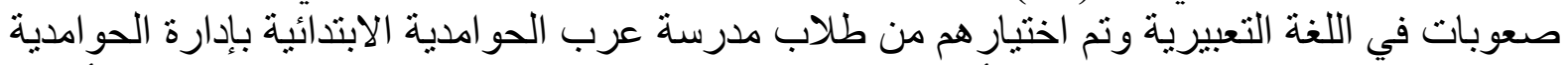

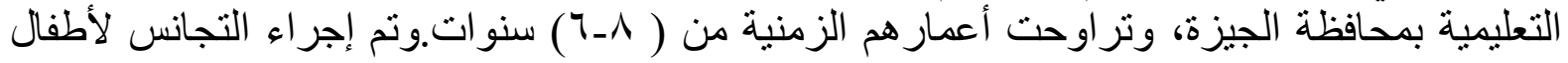

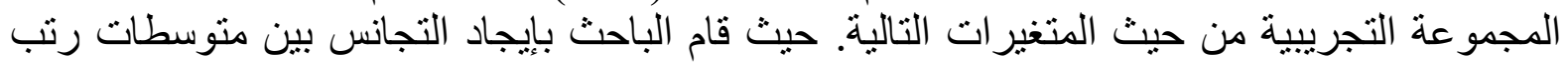
درجات عينة البحث من حيث العمر الزمني كما يتضح من الجدول التئ التالي: 
جدول( () دلالة الفروق بين منوسطات رتب درجات عينة البحث "أطفال المجموعة التجريية"من

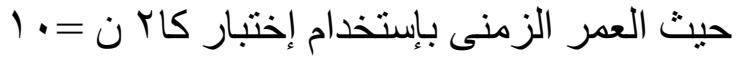

\begin{tabular}{|c|c|c|}
\hline مستوى الدلالة & كاץ & المتغير ات \\
\hline غير دالة & $1 . \wedge \mu$ & العمر الزمنى \\
\hline
\end{tabular}

كاب = 0.0

كاץ = 9.0

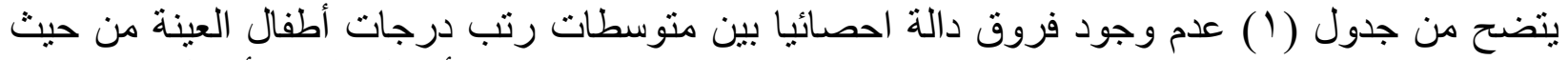

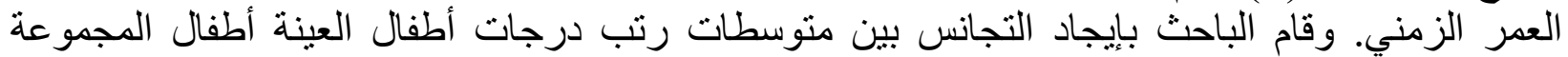
التجريبية دن حيث درجة الذكاء علي اختبار مقياس ستانفورد بينية الصورة الخامسة تقنين صفوت داتئ فرجات

جدول(Y) دلالة الفروق بين متوسطات رتب درجات عينة البحث "اطفال المجموعة التجريية"من

حيث درجة الذكاء علي مقياس ستانفورد بينية الصورة الخامسة بإستخدام إختبار كاب ن = = 1.

\begin{tabular}{|c|c|c|}
\hline مستوى الدلالة & كاr & المتغير ات \\
\hline غير دالة & 1.87 & الذكاء \\
\hline
\end{tabular}

كاب = 11.0

كاY = 9.0

يتضح من جدول (Y) عدم وجود فروق دالة احصائيا بين متوسطات رتب درجات أندات أطفال العينة من حيث درجة الذكاء،كما قام الباحث بإيجاد التجانس بين متوسطات رتب درجات درات عينة البحث "أطفال المجموعة

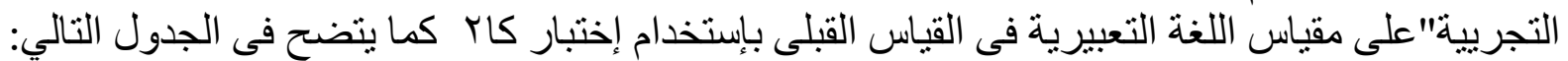

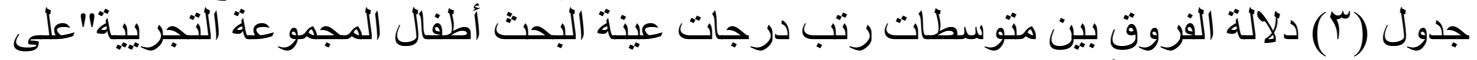

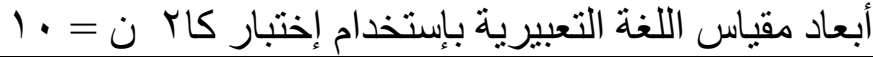

\begin{tabular}{|c|c|c|}
\hline مستوى الدلالة & كاr & إجمالي المقياس \\
\hline غير دالة & 1.41 & بعد تكوين الجمل \\
\hline غير دالة & I.YA & بعد المحتوي \\
\hline غير دالة & $1 . M$ & بعد الوظيفة \\
\hline غير دالة & $1 . Y \varepsilon$ & إجمالي اللغة التعبيرية \\
\hline
\end{tabular}

يتضح من الجدول السابق أن قيمة كاب غير دالة إحصائيا بين أطفال عينة البحث من حيث أبعاد اللغة التعبيرية الثناث.

\section{معاييز اختيار العينة:-}

قام الباحث بمجانسة أطفال العينة من حيث العمر ونسبة العبة الذكاء ومستوى الصعوبات في اللغة التعبيرية لدي

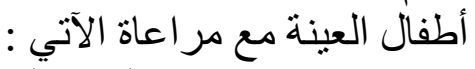

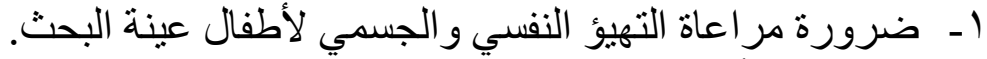

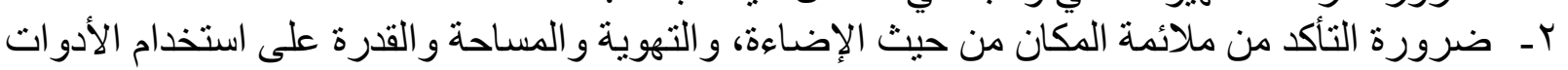

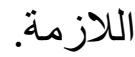
r- أن يتم تطبيق الاختبار ات بصورة فردية لكل طفل على حده. 
عـ ضرورة مر اعاة اجراء الاختبارات وتطبيق أنشطة البرنامج فى بدء اليوم تجنباً لتعرض الأطفال لـ اللإر هاق.

هـ ـ ير اعى اعطاء فترة راحة للطفل خلال تطبيق أدوات الدراسة حتى لا يشعر بالإرهاق أو الملل و التعب.

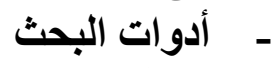

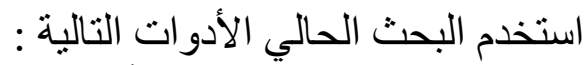

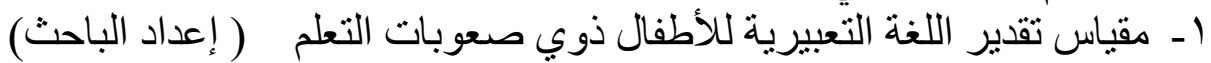

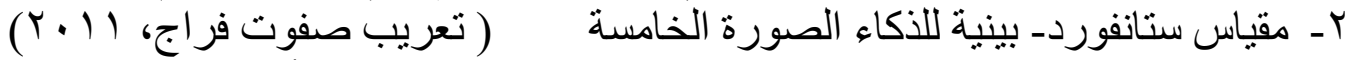

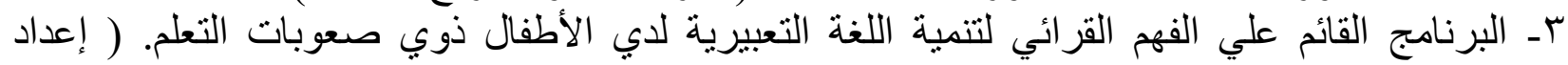
(الباحث)

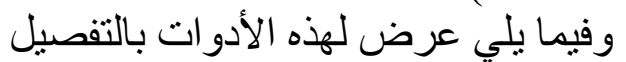

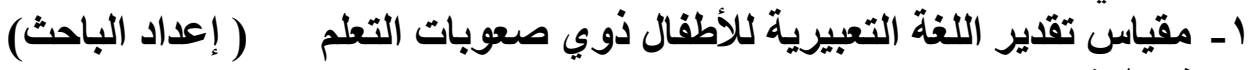

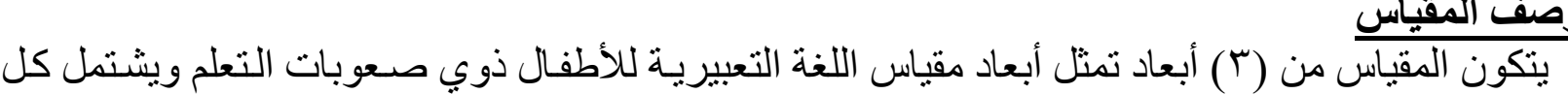

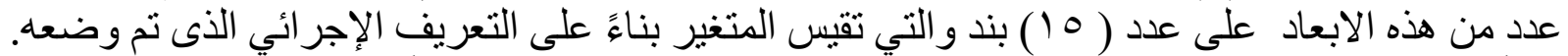

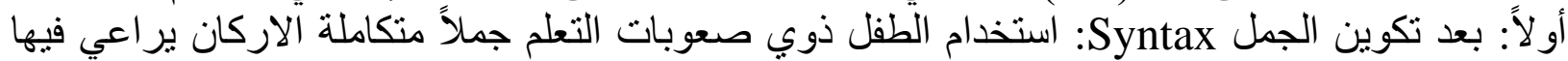

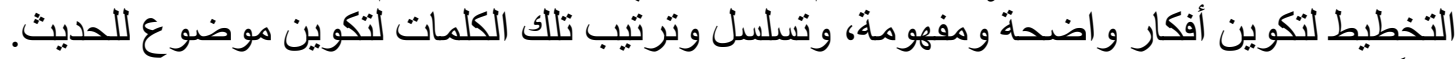

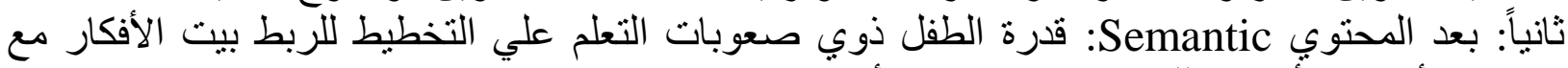

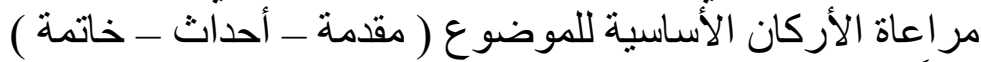

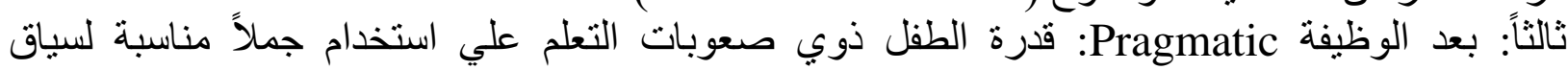
الموضو ع بحيث يعبر بها عن احتياجاته ور غباتها. الكفاءة السيكومترية للمقياس.

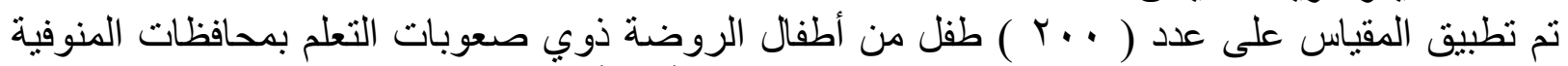

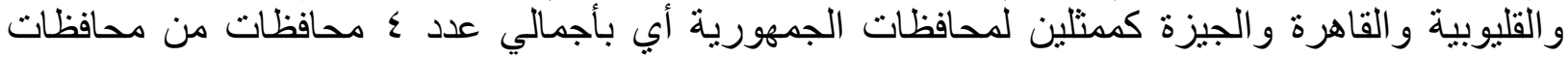

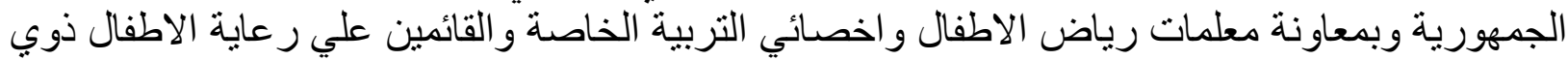

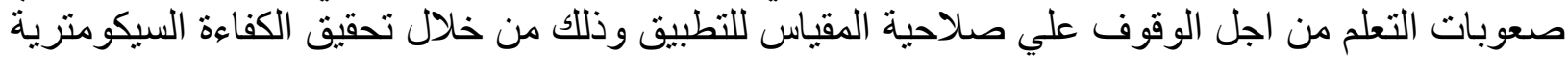

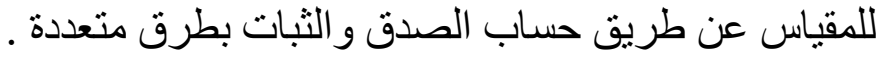

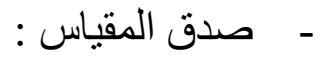

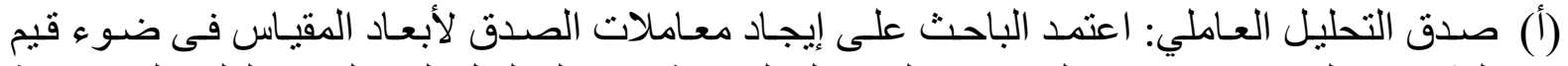

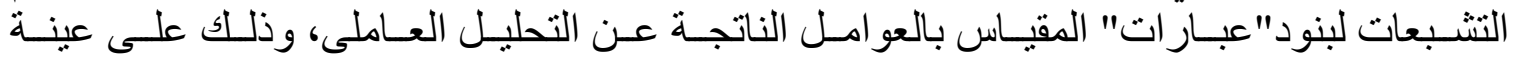

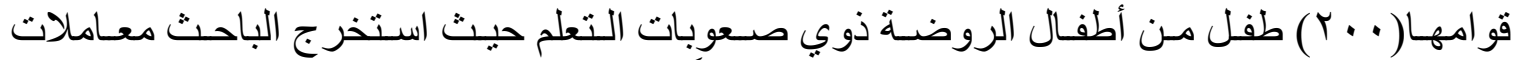

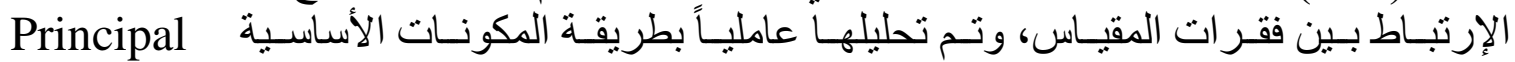

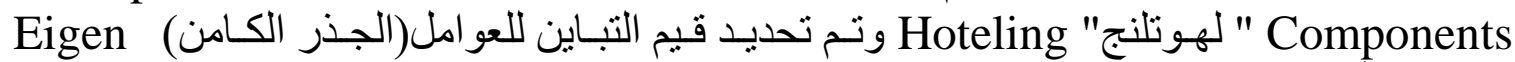

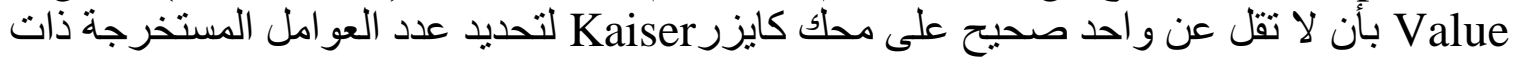

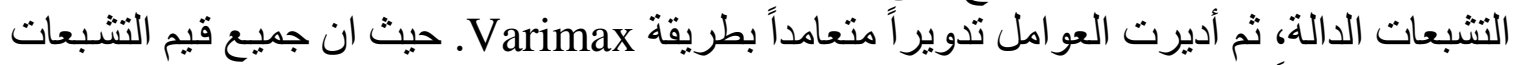

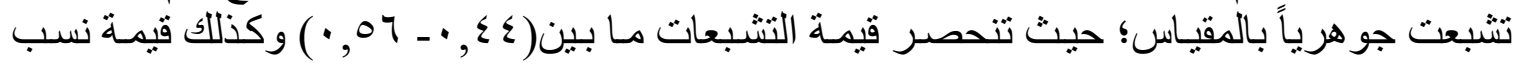

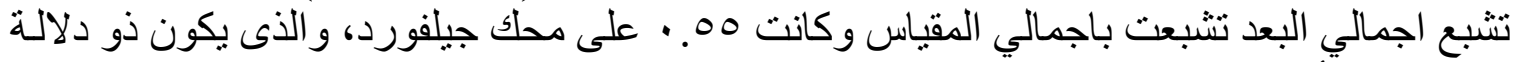

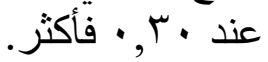




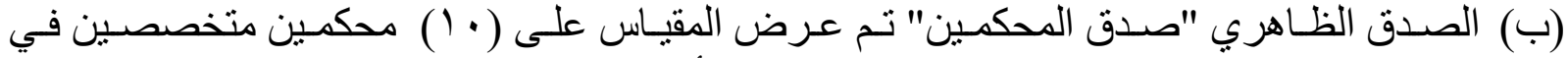

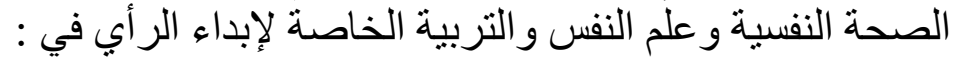

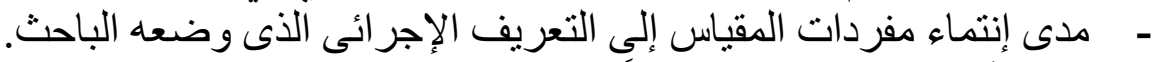

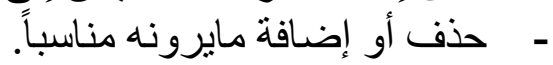

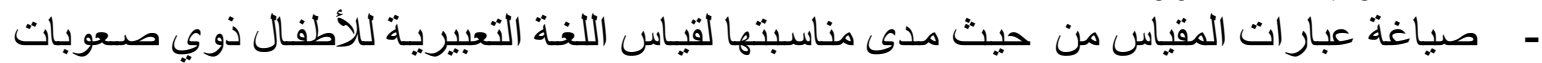
التعلم

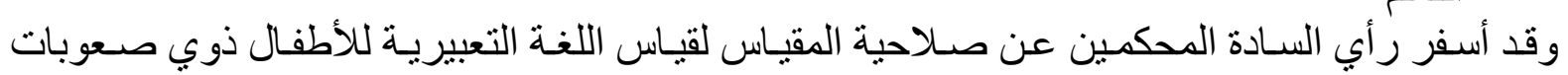
التعلم، حيث تم صـياغة المقياس في صورته النهائية بعد اختيـار العبـار ات التي وصـلت نسبة الاتفـاق

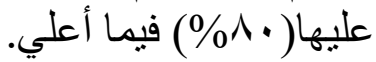
(ج) صدق الاتساق الداخلي: تم حساب صدق الاتساق الداخلي للمقياس باستخدام معامل ارتباط بيرسون

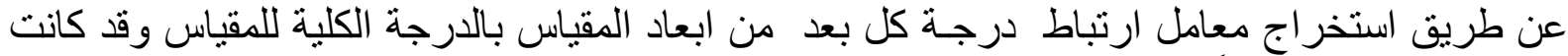

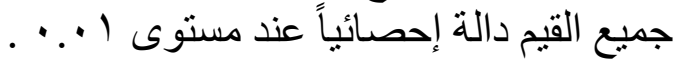
- - ثبات المقياس

(أ) معامل الثبات بطريقة إعادة التطبيق: قام الباحث بإيجاد معاملات الثبات لأبعاد المقياس، و المقياس ككل

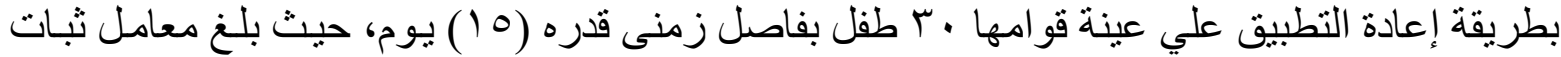

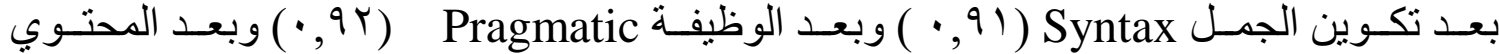

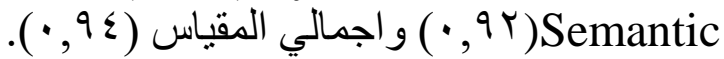
(ب) معاملات الثبات (ألفا) كرونباخ : اعتمد الباحث على إيجاد معاملات الثبات لمقياس اللغة التعبيرية

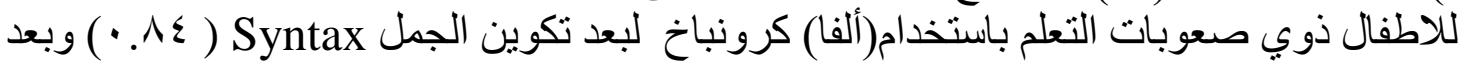

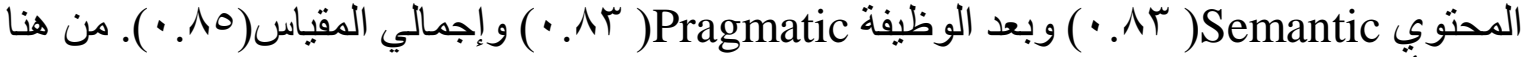

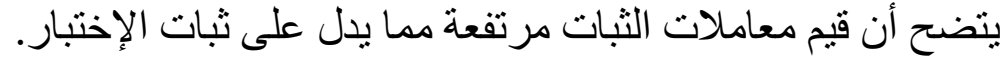

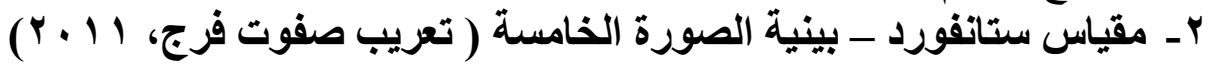

وصف المقياس:

أعده جال رويد Gale H.Roid في الولايات المتحدة الامريكية وقام صفوت فرج بتعريب هذا المقياس وتقنينه علي البيئة المصرية، ويطبق مقياس ستانفورد - بيينة الصورة الخامسة بشكل فردي لتقبيم الذكاء

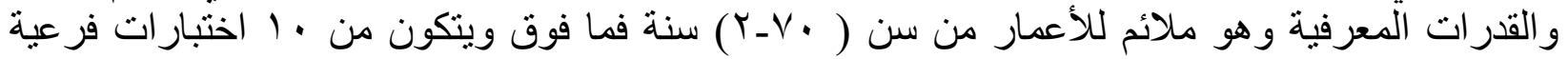
تتجمع مع بعضا لتكون مقاييس اخري وهي وهي: ا ـ مقياس نسبة ذكاء البطارية المختصرة ويتكون من اختباري تحديد المسار وهما اختبار سلاسل هئل

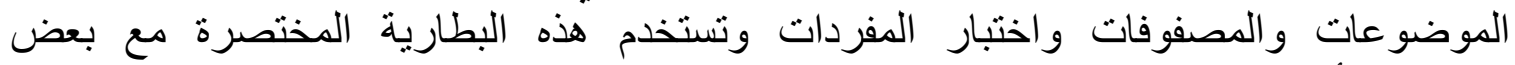

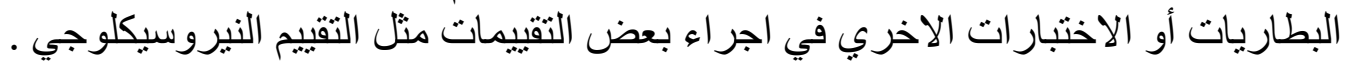

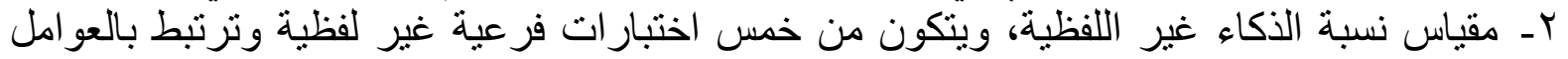

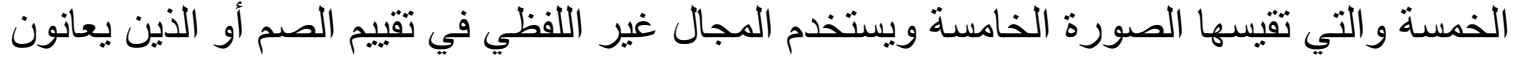

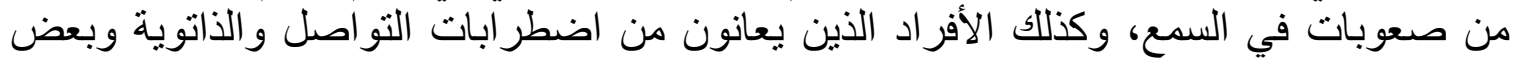

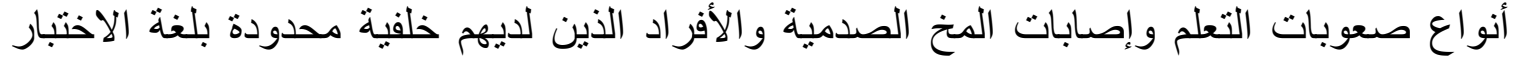

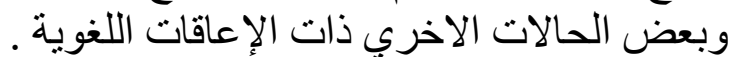

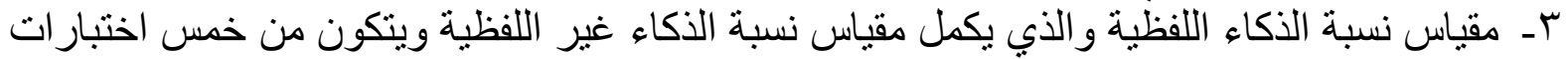

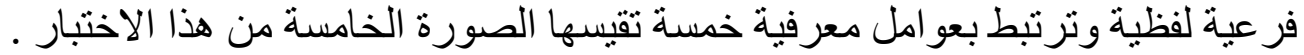

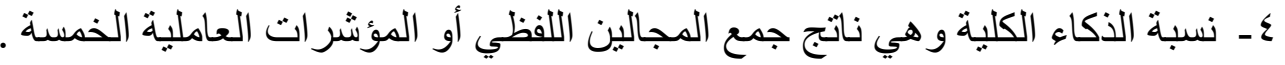


الكفاعة السيكومترية للمقياس

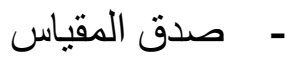

تم حساب صدق المقياس بطريقتين: الأولي هي صدق التمييز العمري، حيث تم قياس قدرة الاختبارات

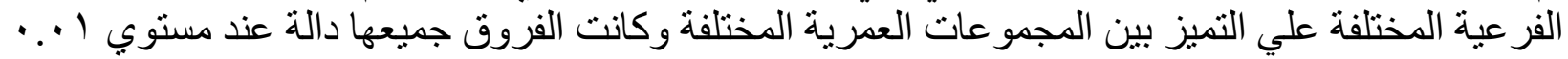

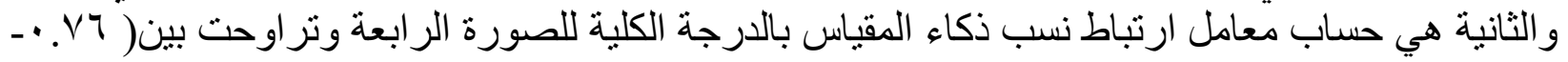

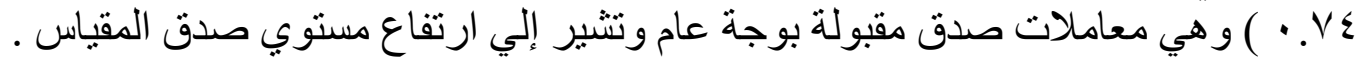

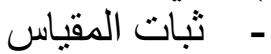

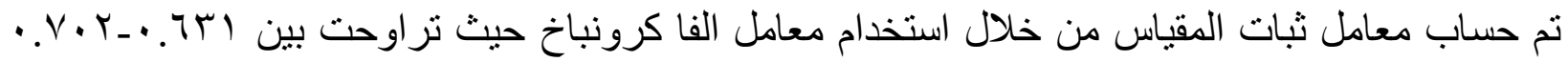

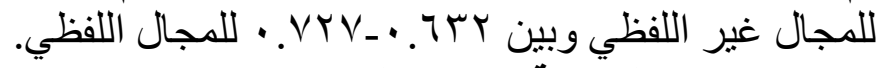

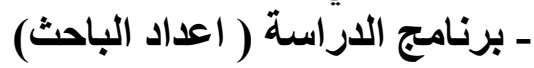

\section{ـ ت تحليد الهاف العام للبرنامج.}

تحسين مستوي اللغة التعبيرية للأطفال ذوي التوبي صعوبات التعلم. في الفئة العمرية من( ع ـ ؟) سنوات.

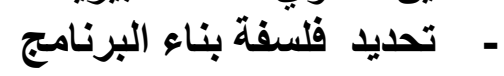

من أهم مؤشرات جودة بناء أى برنامج أن تبدأ بتوضيح الفلسفة التربوية التى تبنى عليها ـ ـولقد تم التأكيد

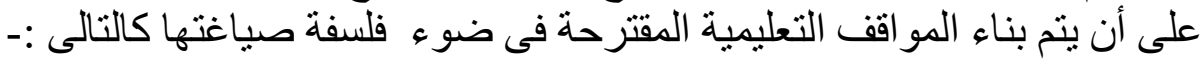

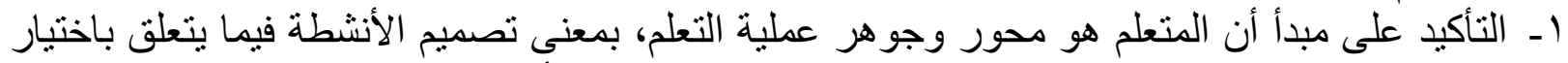

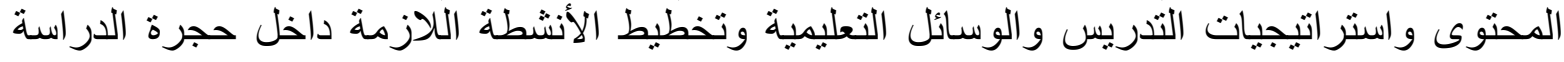

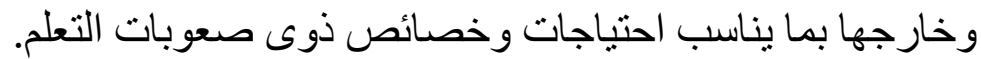

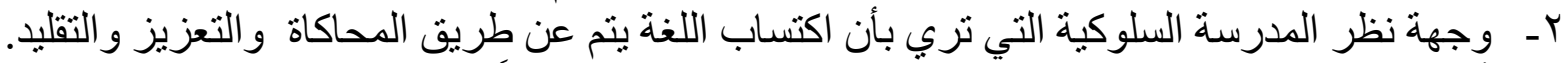

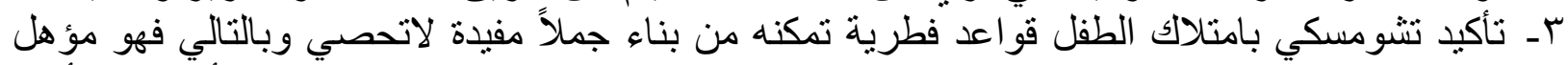

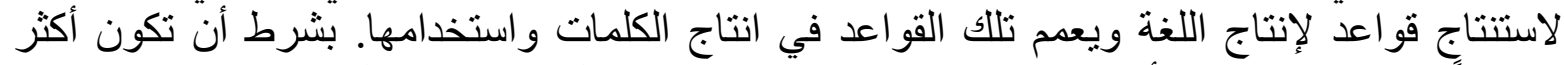

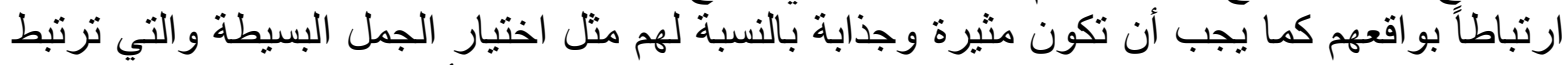

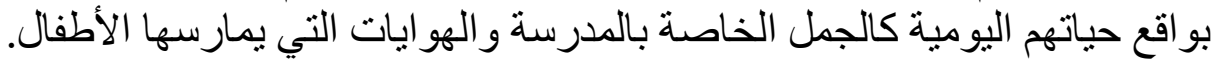


- ملعات للبرنامج التدريبي.

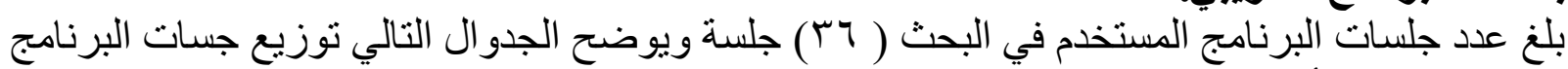

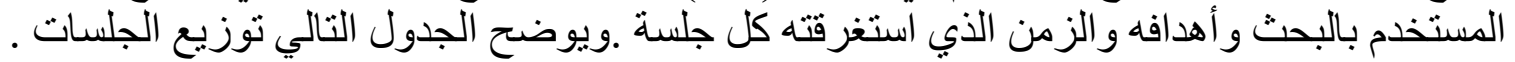

جدول (V) توزيع جلسات البرنامج الجنات

\begin{tabular}{|c|c|c|c|c|c|c|c|}
\hline \multirow{2}{*}{ الجلسات } & \multicolumn{2}{|c|}{$\begin{array}{c}\text { الوظيفة } \\
\text { Pragmatic }\end{array}$} & \multicolumn{2}{|c|}{$\begin{array}{c}\text { المحتوي } \\
\text { Semantic }\end{array}$} & \multicolumn{2}{|c|}{$\begin{array}{r}\text { التكوين } \\
\text { Syntax }\end{array}$} & \multirow{2}{*}{ 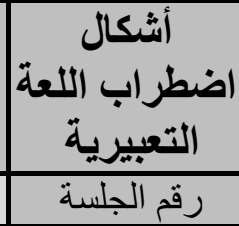 } \\
\hline & |الهذف العام & عنو ان الجلسة & |الهدف العام & عنوان الجلسة & الهذف العام & عنوان الجلسة & \\
\hline | & \multirow{4}{*}{ المناسبة } & الموضو عناوين & \multirow{4}{*}{ موضكامل } & وصف المدرسة & \multirow{4}{*}{ التاج جنكاملة } & عبار ات اسمية & $1 / 2 / 3$ \\
\hline مr دقيقة & & التعبير عن الأداء & & وصف حديقة & & المفردــ الجمع & $4 / 5 / 6$ \\
\hline | مب دقيقة & & توظيف الأفكار & & شكر أ للك & & ضمائر الفاعل & $7 / 8 / 9$ \\
\hline |0ب دقيقة & & تحديد الفكرة & & طفل مثالي & & أقسام الكلام & $10 / 11 / 12$ \\
\hline | & \multirow{4}{*}{ التعبير عن التخطيط } & اعطاء نتائج & \multirow{4}{*}{ اللربط بين } & الكلمة الناقصة & \multirow{4}{*}{ لتكوين أفكار } & المفرد و المثني & $13 / 14 / 15$ \\
\hline |مب دقيقة & & تكملة الجملة & & الصور المحذوفة & & المذكر و المؤنتث & $16 / 17 / 18$ \\
\hline |مب دقيقة & & تقديم أدلة & & الصحيحة & & الكلمة ومعكوسها & $19 / 20 / 21$ \\
\hline مب دقيقة & & اقتر اح نهايات & & مهام فعلية & & الفعل المضـارع & $22 / 23 / 24$ \\
\hline |0 د دقيقة & \multirow{4}{*}{ ترل الأفكار } & إعادة صباغة & \multirow{4}{*}{ الأسراسية } & المستشفي & \multirow{4}{*}{ لت لتكوين } & الضمائر المنفصلة & $25 / 26 / 27$ \\
\hline |0 د دقيقة & & طرح الأسئلة & & ترتيب الصور & & وصف الفعل & $28 / 29 / 30$ \\
\hline مr دقيقة & & إضـافة أفكار & & سؤ ال وجو اب & & أدو ات الإستفهام & $31 / 32 / 33$ \\
\hline |هr دقيقة & & ابداء رأي & & الأشياء المحبطة & & الفعل الماضي & $34 / 35 / 36$ \\
\hline
\end{tabular}

$$
\text { الخطوات الاجرائية }
$$

اتبع الباحث الخطو ات التالية في سبيل إنجاز البحث:

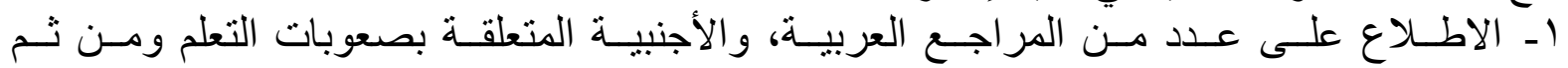

المادة العلمية الخاصة بالإطار النظري للبحث.

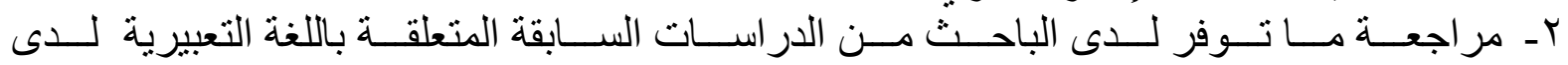
الأطفال ذوي صعوبات التعلم و استخلاص أوجاء الأنه الاستفادة منها.

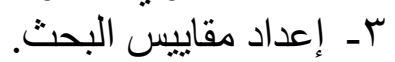

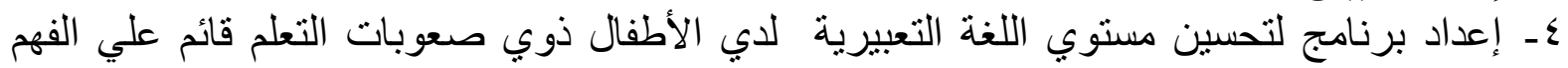

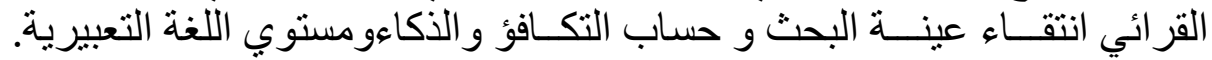
هـ تطبيق أدوات البحث (القياس القبلي) .

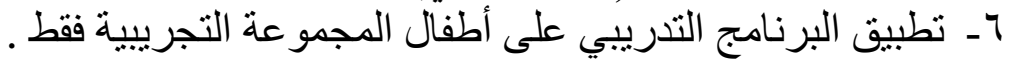
V- جر اء القياس البعدي للمجمو عة التجريبية 
1- إجــراء القيـاس التتبعسي على المجموعـة التجرييـــة وذلك للتحقيق من مدى استمرارية تأثير

$$
\begin{aligned}
& \text { البرنامج. } \\
& \text { 9- معالجة البيانات إحصائياً. } \\
& \text { • 1 ـاستخلاص النتائج وتفسير ها. } \\
& \text { الأساليب الاحصائية المستخدمة }
\end{aligned}
$$

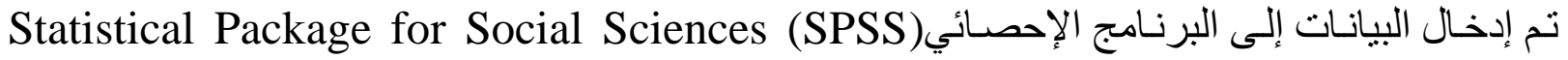
وبو اسطة هذا البرنامج نم حساب الإحصاء الإتات الآتية:

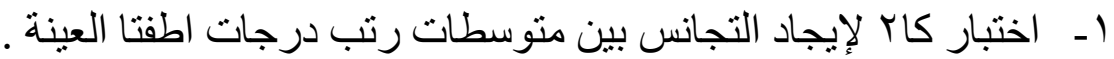

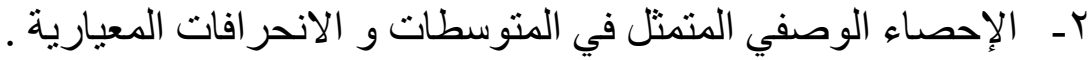

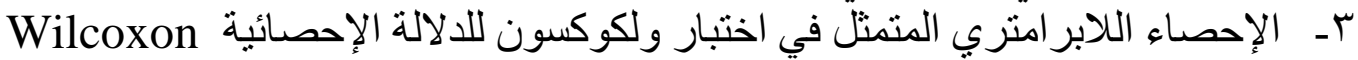

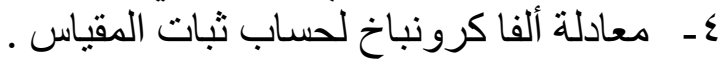

$$
\text { نتائج البحث ومناقشتها }
$$

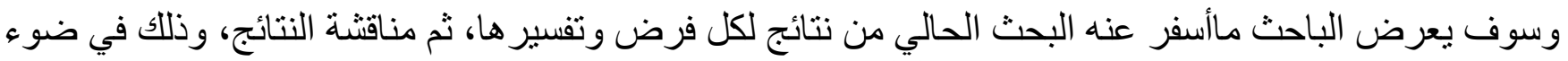

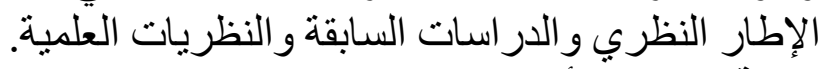

نتيجة الفرض الأول:وكان نصاء:

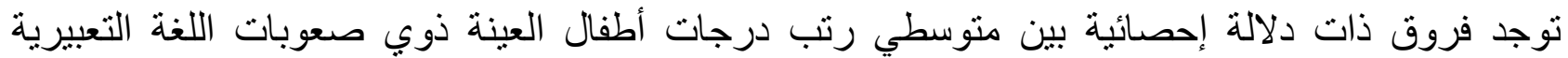

\begin{tabular}{|c|c|c|c|c|c|c|c|}
\hline اتجاه الدلالة & الدلالة & $\mathbf{Z}$ & مجموع & متوسط & العدد & القبلى- البعدى & المتغيرات \\
\hline فلقى اتجاه & مستوى دالة ـ. & $r .970$ & 00 & 0.0 & $\begin{array}{l}- \\
1 . \\
1 .\end{array}$ & الرتب الرتب المونبة الرتبة & بعد تكوين \\
\hline القياس الجباه & مستوى دالة •. & $r .907$ & $00^{\circ}$ & - & $\begin{array}{l}- \\
1 . \\
i .\end{array}$ & 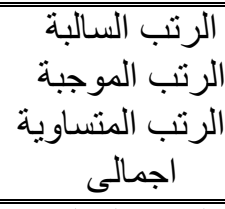 & المحتوي \\
\hline في القياس البعدى & مستوى 1الة عند & r.91^9 & $00^{-}$ & - & $\begin{array}{l}- \\
1 . \\
1 .\end{array}$ & الرتب الرتب الموجنبة الرتبالية & بعد الوظيفة \\
\hline القيآس الجددى & مستوى الـ ـ. & r.qจq & 00 & 0.0 & $\begin{array}{l}- \\
1 . \\
1 .\end{array}$ & الرتب الرتب الموجنبة & المقيالي \\
\hline
\end{tabular}

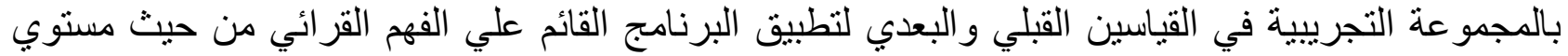

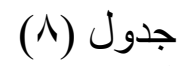
اللغة التعبيرية في اتجاه القياس البعدي.

يوضح الفروق بين منوسطات رثب درجات الأطفال ذوي صعوبات التعلم من حيث تنمية ابعاد اللغة التعبيرية في القياسين القبلي و البعدي على مقياس اللغة التعبيرية ندئ • 


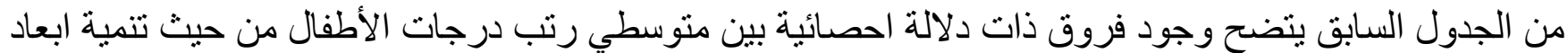

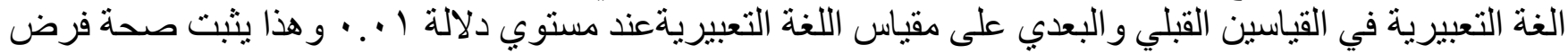
البحث الحالي .وهذا ما يوضحة الثكل التالي:

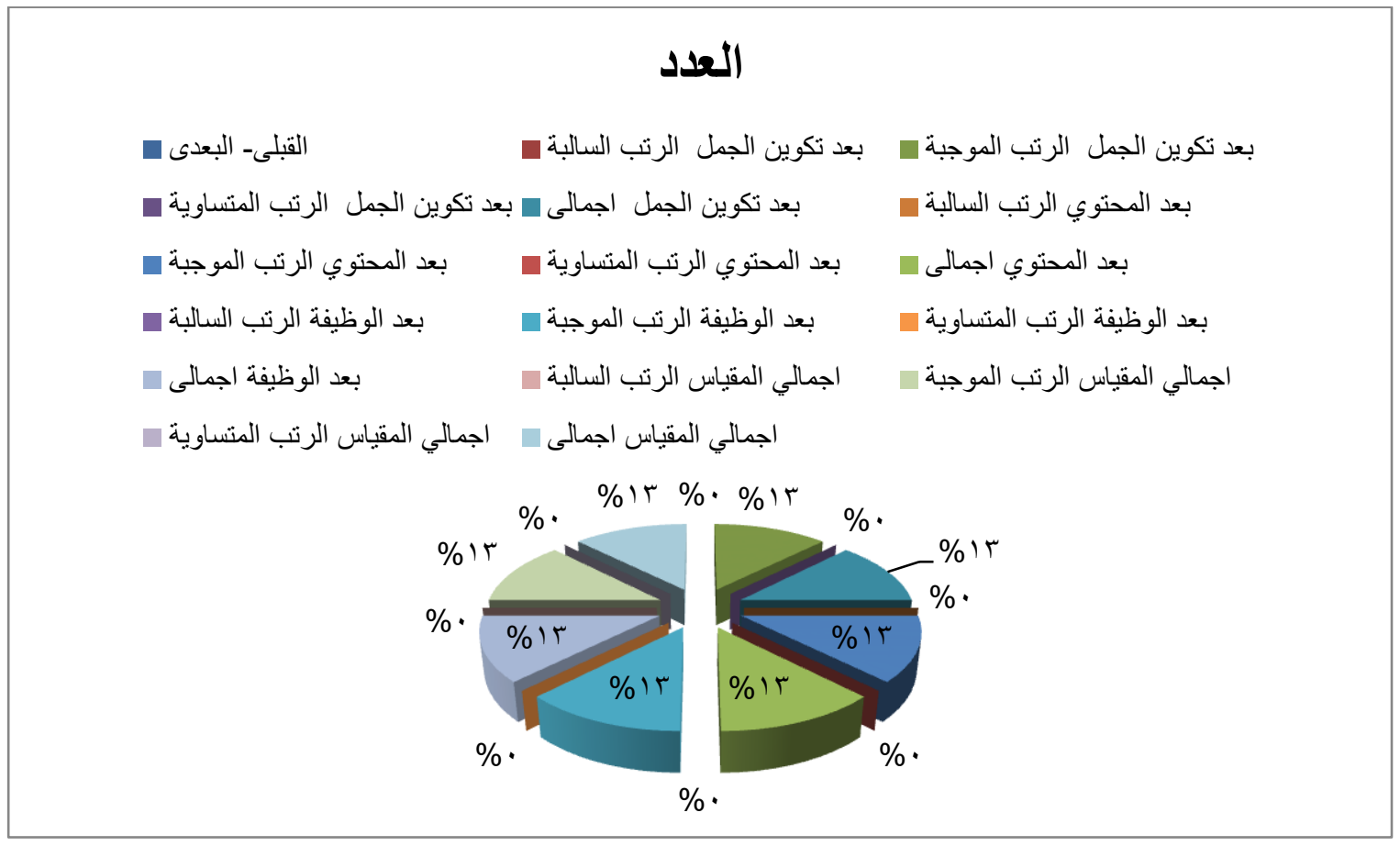

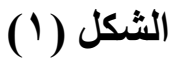

الفروق بين منوسطات رتب درجات الأطفال من حيث تتمية ابعاد اللغة التعبيرية في القياسين القبلي و البعدي على مقياس اللغة التعبيرية

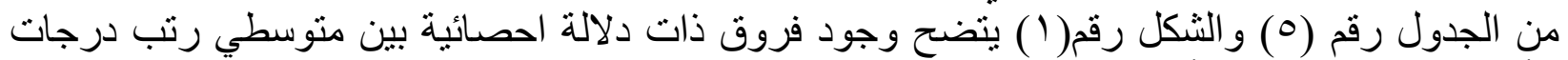

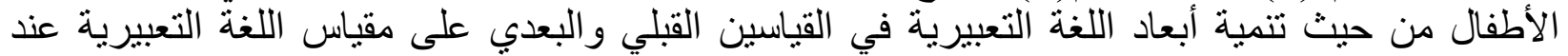

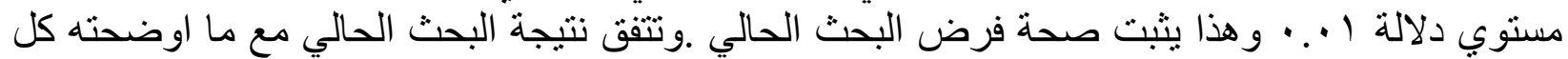

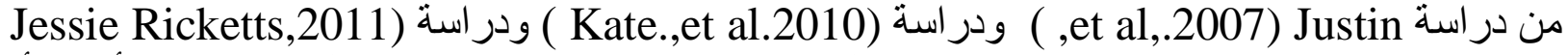

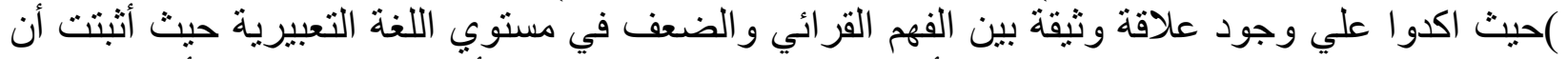

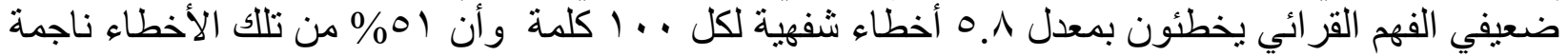

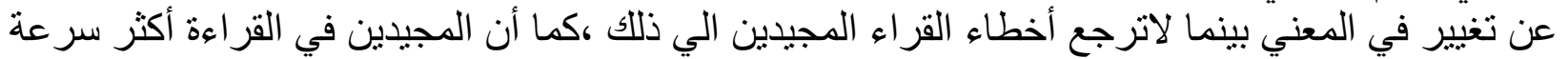

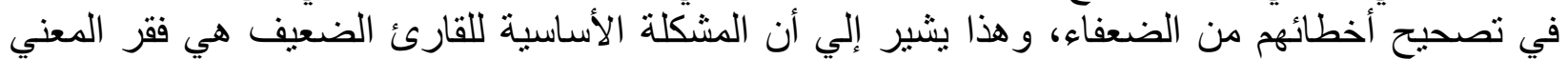

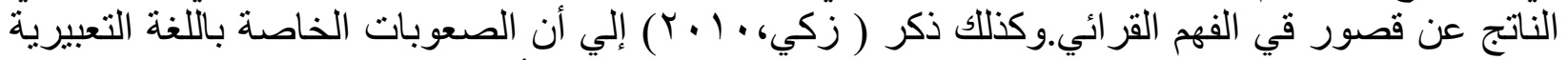

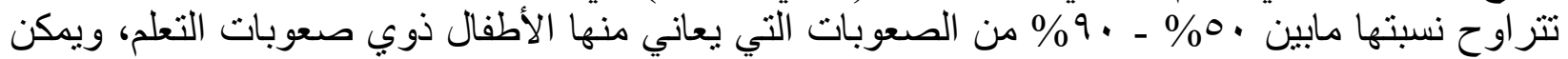

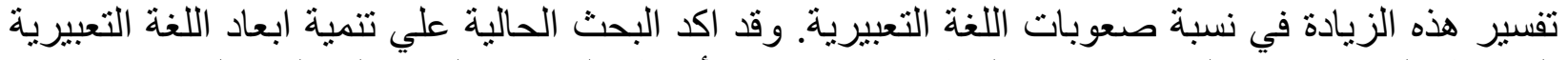

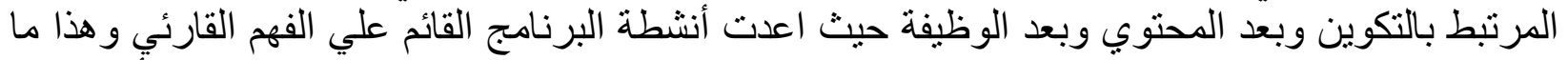

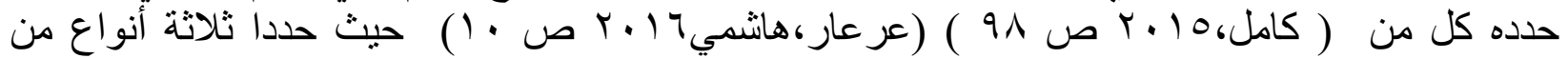
اضطر ابات اللغة التعبيرية تتفق مع ما تم تتميته في البحث الحالي، حيث بشير التهيث التكوين إلي تركيب الجملة،

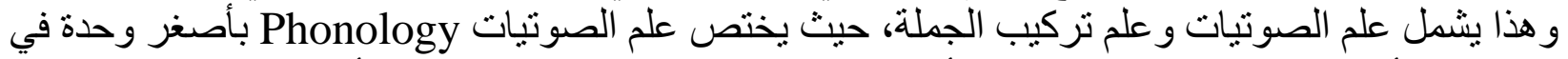

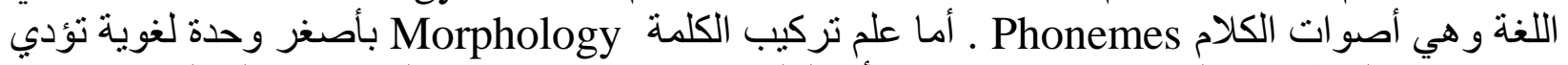
معني و هي المقطع ذو المعني Morpheme ويختص علم تركيب الجملة Word أو الكلمة 


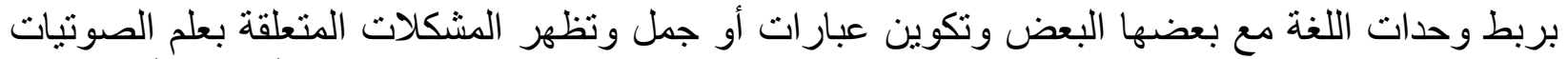

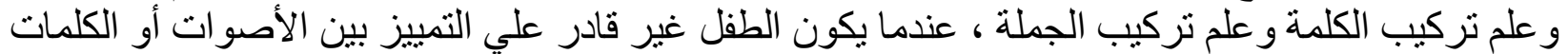

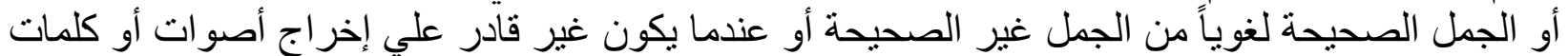

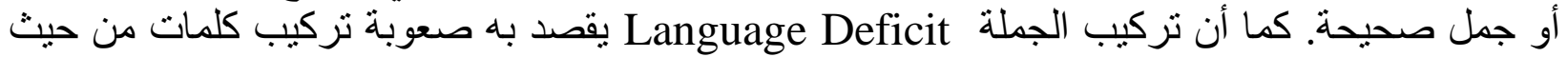

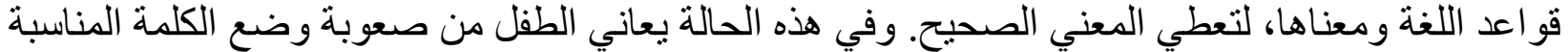

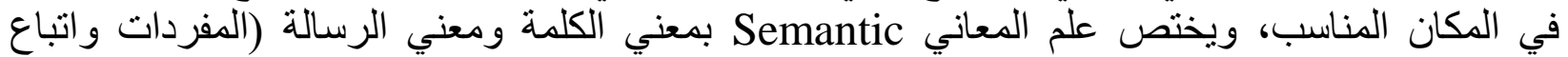

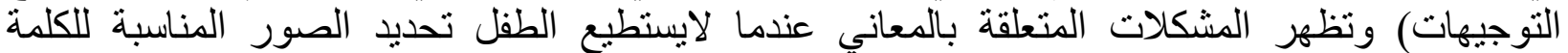

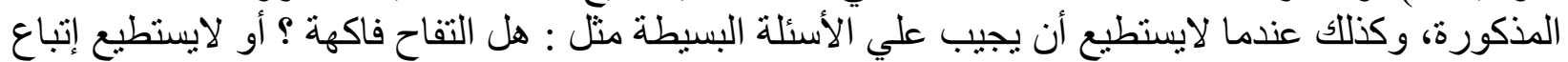

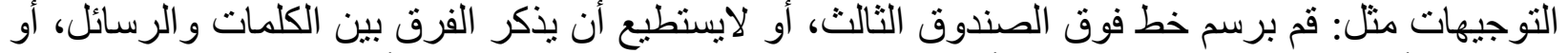

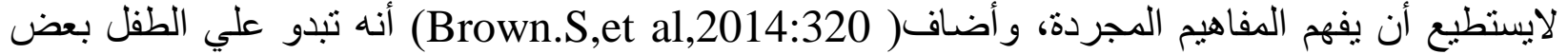

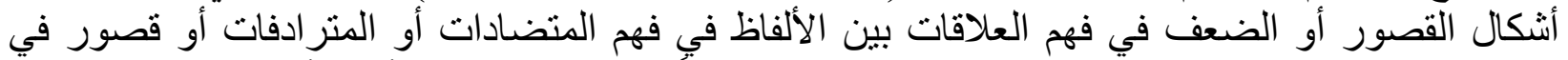

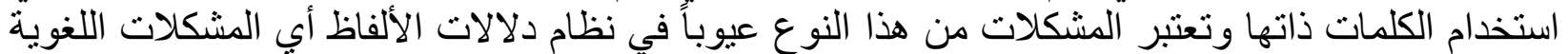

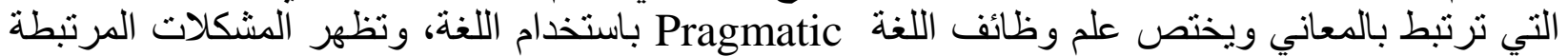

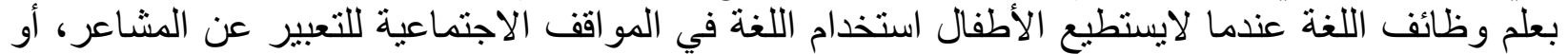

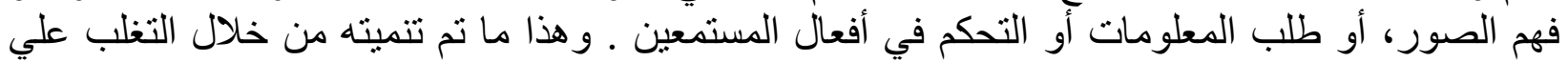
الششكلات الخاصة بكل بعد من ابعاد اللغة التعبيرية السابقة من خلال برنامج يعتمد علي الفهم القر ائي.

نتيجة الفرض الثاني وكان نصه:--

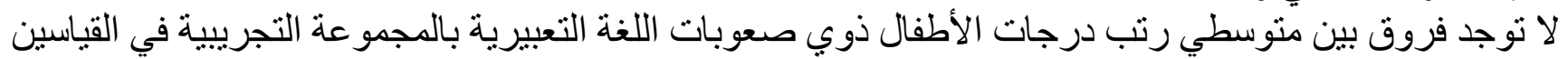
البعدي و التتبعي لتطبيق البرنامج القائم علي الفهم القرائي من حيث تنمية اللغة التعبيرية بعد مرور شهر من القيات القياس

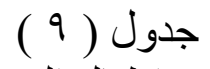

البعدي.

يوضح الفروق بين منوسطات رتب درجات اطفال المجمو عة التجرييية اطفال العينة في القياسين

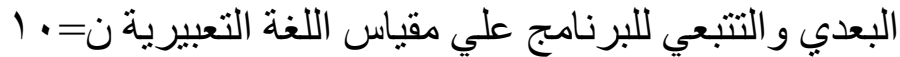

\begin{tabular}{|c|c|c|c|c|c|c|c|}
\hline جاه الدلالة & الدلالة & $\mathbf{Z}$ & |الرجموع & متوسط & العدد & القبلى- البعدى & المتغيرات \\
\hline فلى اتجاه البعدى & مسنوى دالة علـ & $1, r \varepsilon$. & $0_{0}^{-}$ & $\begin{array}{l}.0 \\
r .0\end{array}$ & $\begin{array}{l}- \\
r \\
1 \\
1 .\end{array}$ & الرتب الرتب المتوجبة الربة & بعد تكوين \\
\hline القياس الجعدى & مستوى لد لـ. & $1 . \varepsilon r$. & $\bar{v}$ & - & $\begin{array}{l}1 \\
1 \\
1 \\
1 .\end{array}$ & الرتب الرتب الموجابة الرتبة & المحتوي \\
\hline فئى الجاه البعدى & مستوى 1الة ع. . & $1 . r \pi$. & v. & $\begin{array}{l}- \\
\text { r.0 }\end{array}$ & $\begin{array}{l}- \\
\bar{r} \\
v \\
1 .\end{array}$ & الرتب الرتب الموجابة الرتبة & الوظيفة \\
\hline القيأس البجدى & | مستوى 1الة عند . & . & V.O & r. & $\begin{array}{l}1 \\
1 \\
1 \\
1 .\end{array}$ & الرتب الرتب الموجنبة الربالبة & المقياس \\
\hline
\end{tabular}


من الجدول السابق يتضح عدم وجود فروق بين منوسطات رتب درجات الأطفال من حيث تنمية اللغة التعبيرية في القياسين البعدي و التتبعي للبرنامج على مقياس اللغة التعبيرية عند ابي مستوي دلالة ونذات وذا ما يوضحه الثنكل

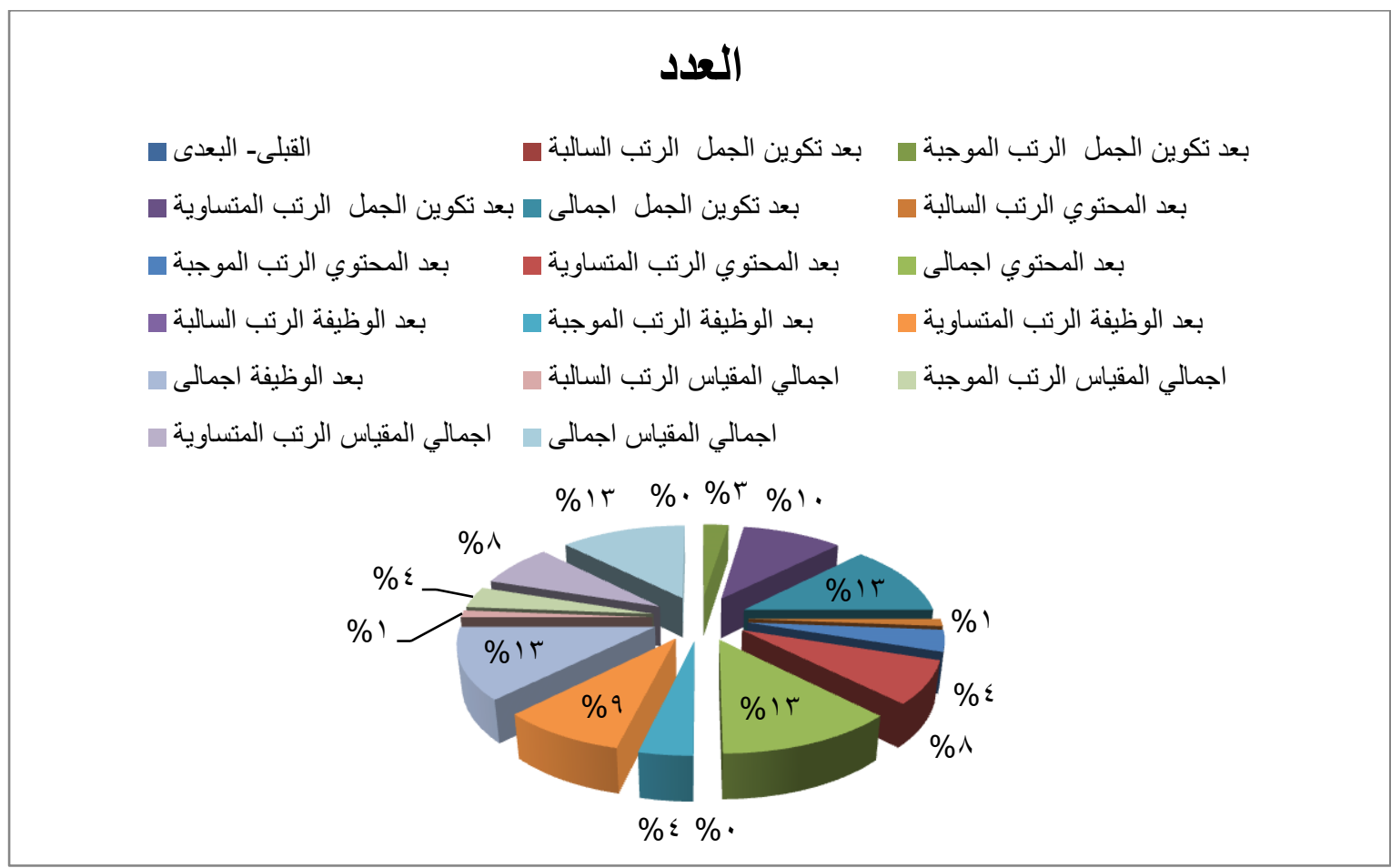

(الثكل رقم (r) (ب)

يوضح عدم وجود فروق بين منوسطات رتب درجات الأطفال من حيث تنمية اللغة التعبيرية في القياسين

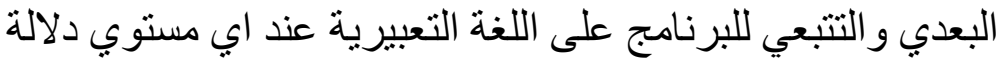

مناقشة نتيجة الفرض الثاني:

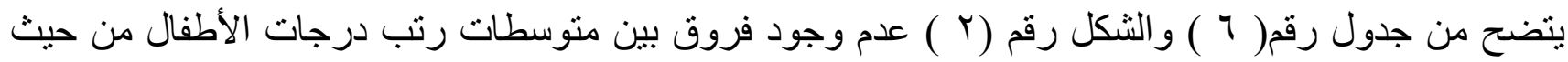

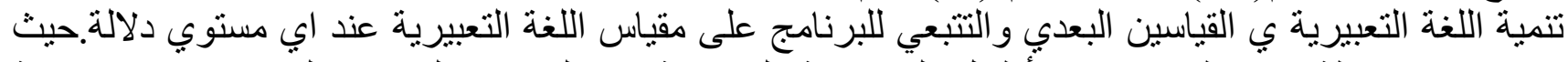

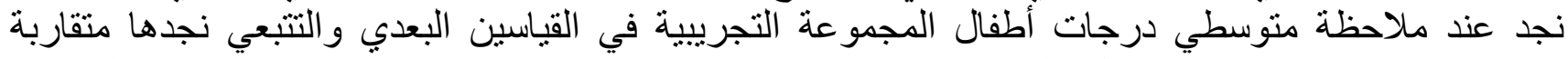

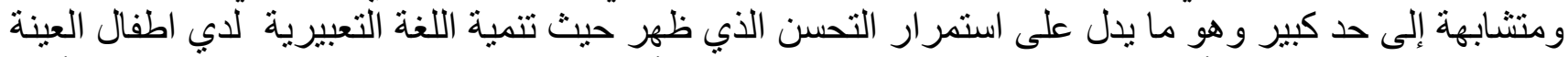

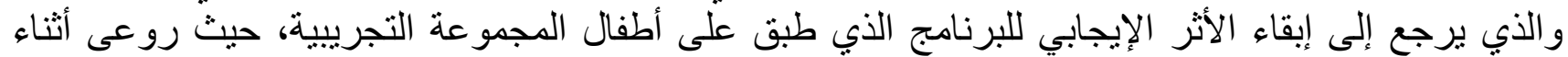

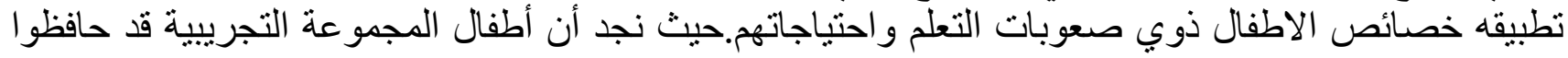

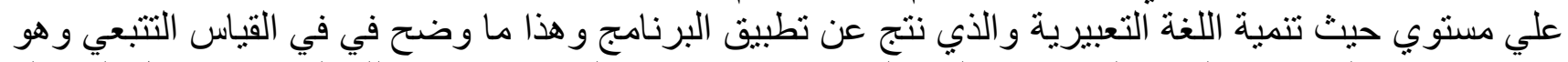

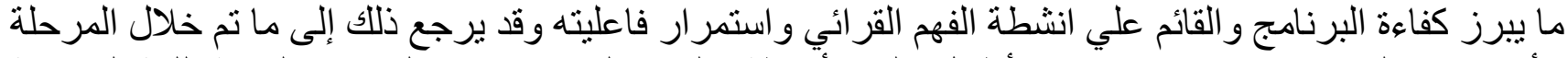

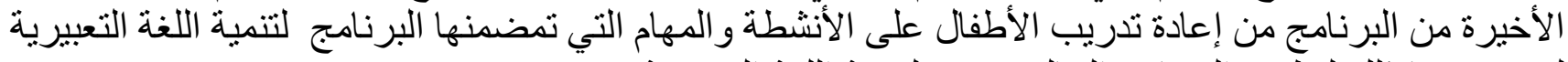
لديهم. دفعنا ذللك لتطبيق البرنامج الحادة الحالي حيث لتنمية اللغة التعبيرية. 


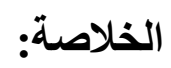

اسفر البحث الحالي عن النتائج التالي:

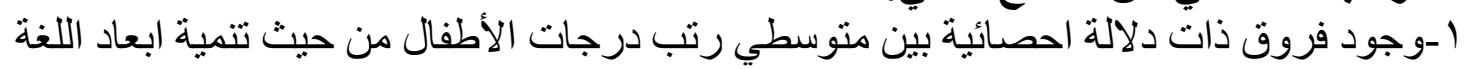

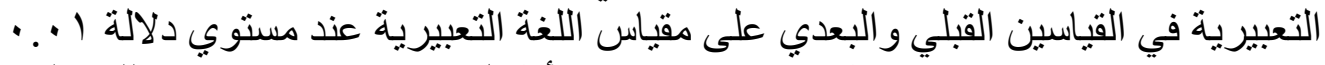

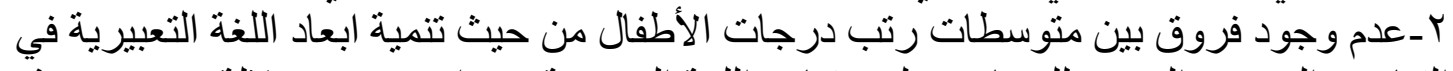

القياسين البعدي و التتبعي للبرنامج على مقياس اللغة التعبيرية عند اي مستوي دلالة التة بعد مرور شهر ون

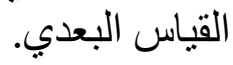

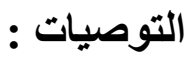

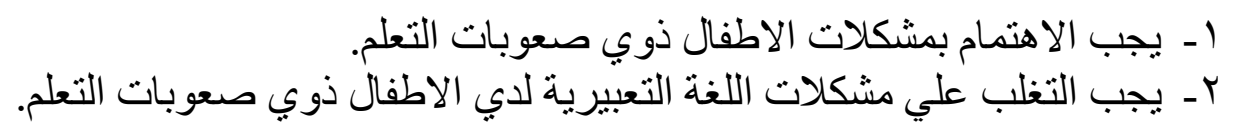

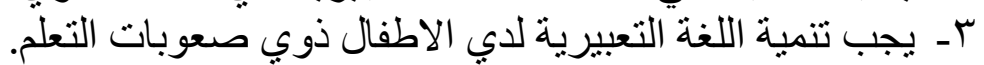

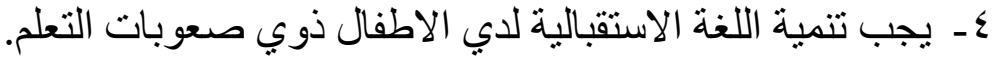

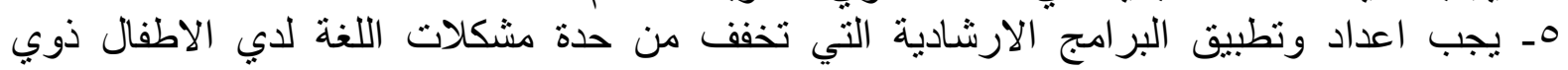

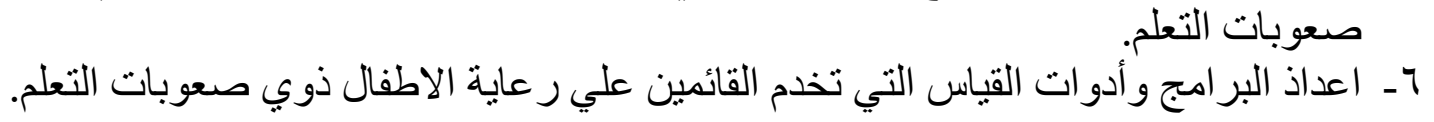




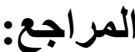

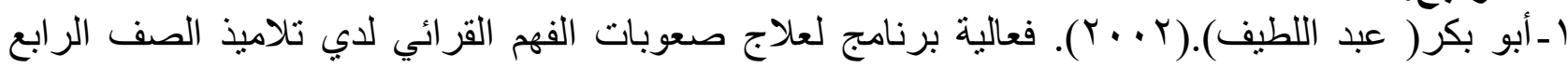
الابتدائي فس ضوء نظرية إلمعات السياق لسيترنبرج، القاهرة، مجلة دراسات في المناهج وطرق التدريس

العدد 99

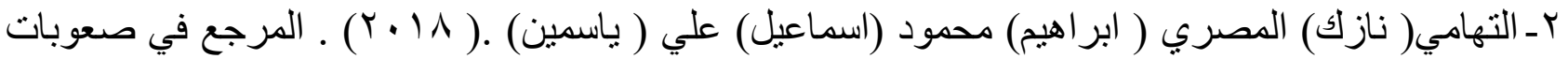

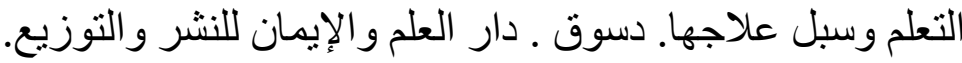

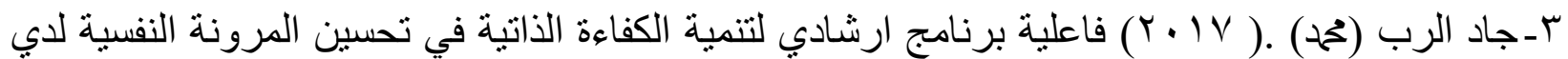

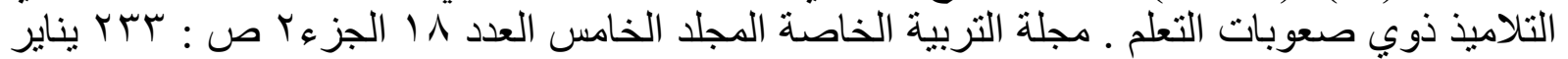
$r .1 V$ ع -جال ( رويد).( (1) • (Y) . مقياس ستانفورد - بينية الصورة الخامسة.(ترجمة وتقنين للبيئة المصرية :

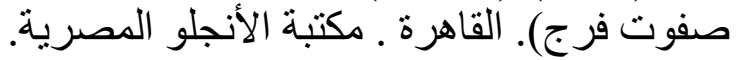

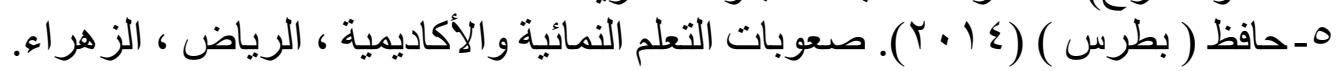

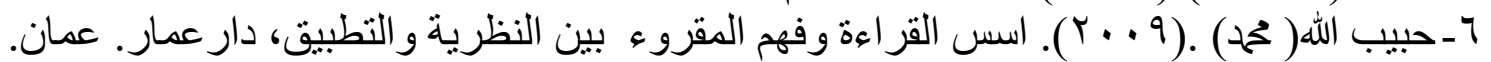

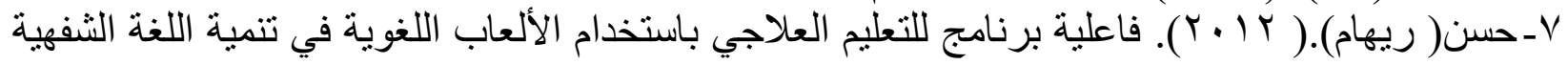

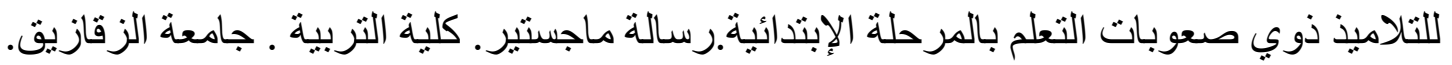

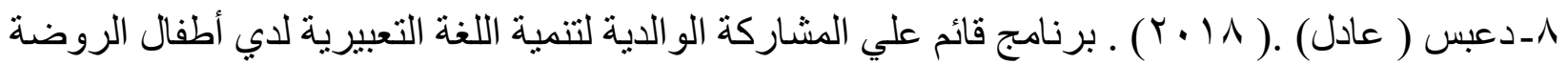

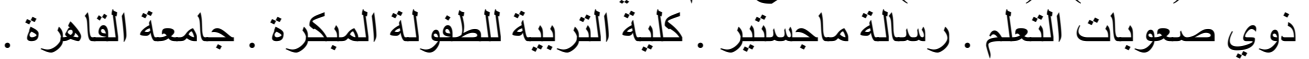

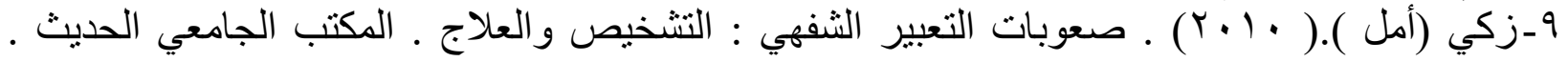
الاسكندرية

• ـ زياد ( كامل) الزبيري( شريفة ) كامل( صائب) الجلامدة ( فوزية ) حسونة ( مأمون) الثرمان. (

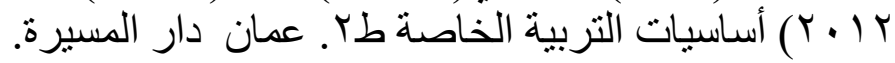

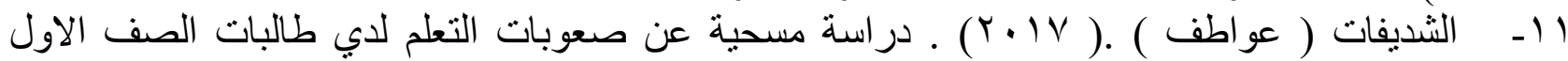
المتوسط في مكة المكرمة باستخدام مقياس تقييم صعوبات التعلم R2-LDES مجلة الجامعة الاسلامية

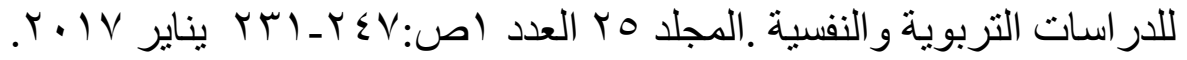

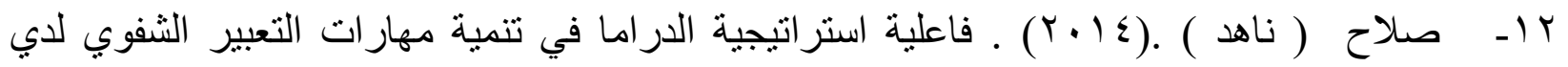

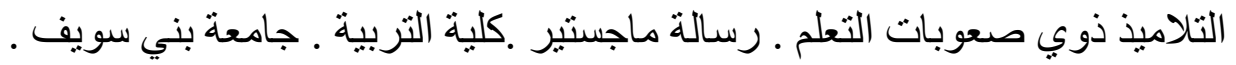

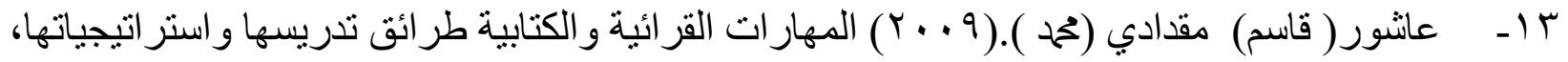

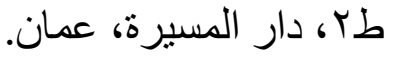

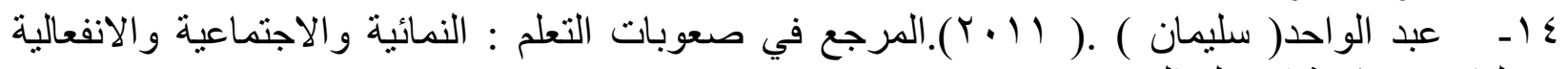

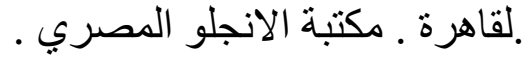

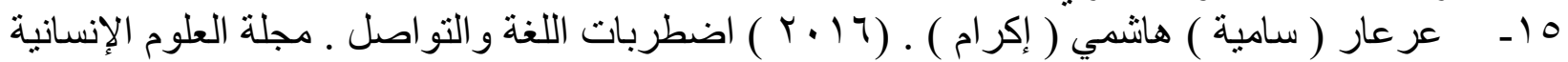

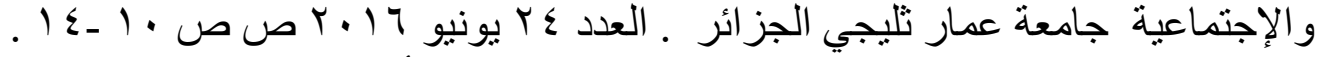

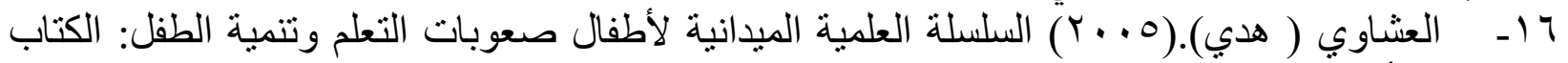

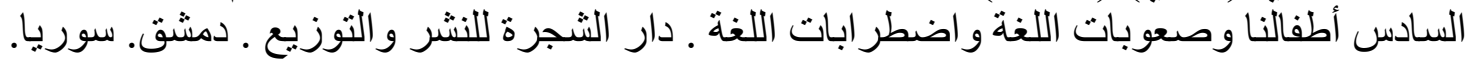
IV

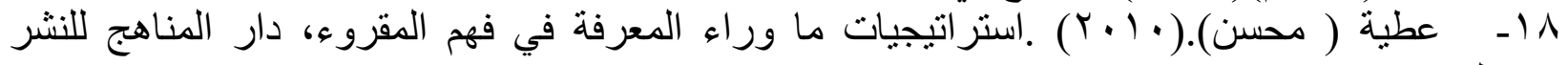
و التوزيع، عمان. 


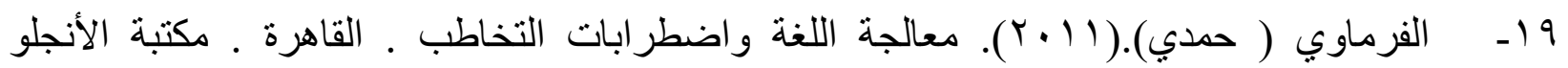

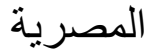

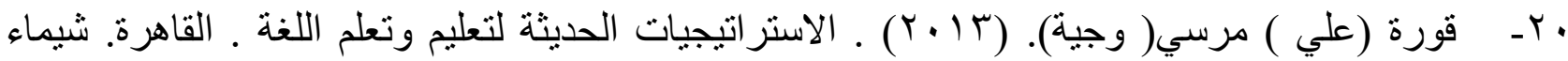
للطبع و النشر.

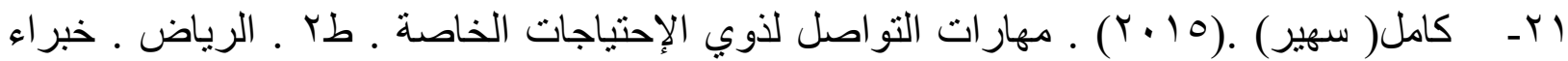
التزبية

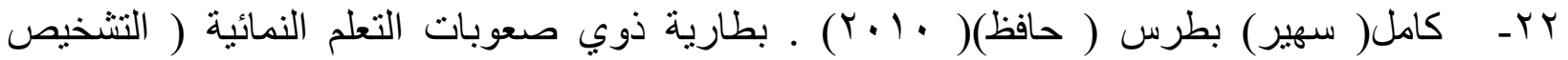
و التدخل) القاهرة. مكتبة الأنجلو.

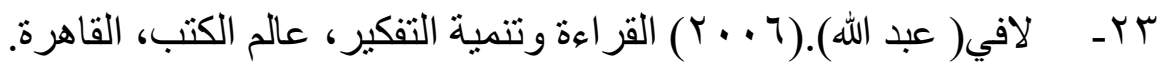

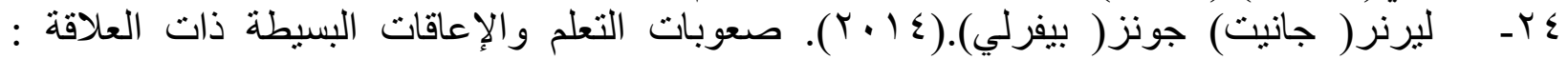

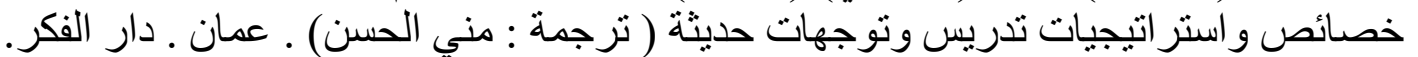

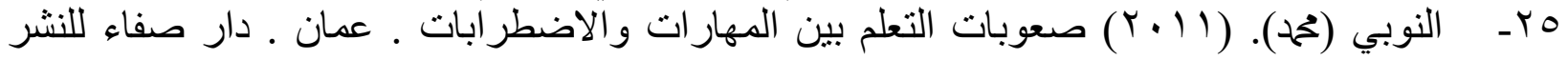
و التوزيع.

جr - يونسع( فتحي). تعليم اللغة العربية للمبتدئين الصغار و الكبار ، القاهرة ، كلية التربية - جامعة عين شمس.

27- Anderson, Alida; Berry, Katherine A. (2017). Tableau's Influence on the Oral Language Skills of Students with Language-Based Learning Disabilities. Learning Disabilities: A Multidisciplinary Journal, v22 n1 p1-20.

28- Andrea E., Philip H. \& Gina C. (2013). Markers for persistent specific expressive language delay in 3-4-year-olds. international journal of language communication disorders. Vol. 48, No. 5, 534-553.

29- Brown, Shannon Harris; Lignugaris-Kraft, \& Forbush E. (2014) The Effects of Morphemic Vocabulary Instruction on Prefix Vocabulary and Sentence Comprehension for Middle School Students with Learning Disabilities Education and Treatment of Children, v39 n3 p301-338.

30- Cornoldi.C., Oakhill.J, (2012) Reading comprehension. Lawrence Erlbaum Associates, Inc., Publishers.Mahwah, New Jersy.USA

31- David M. (2013). Dictionary of communication disorders. Fourth Edition. Whurr publishers. London. UK.

32- Donald. D (2014). The State of learning disabilities Application disabilities University of California. San Francisco.

33- Gina Conti-Ramsden \& Kevin Durkin (2012) Language Development and Assessment in the Preschool Period. Neuropsychology Review December 2012, Volume 22, Issue 4, pp 384-401.

34- Henry.L(2015). Executive functioning and verbal fluency in children with language difficulties. Learning and Instruction Volume 39, October 2015, Pages 137-147. 
35- Jessie Ricketts. (2011). Research Review: Reading comprehension in developmental disorders of language and communication. Journal of Psychology and Psychiatry. Volume52, Issue11. Pages 1111-1123

36- Justin C. Wise, Rose A. Sevcik, Robin. (2007). The Relationship Among Receptive and Expressive Vocabulary, Listening Comprehension, Pre-Reading Skills, Word Identification Skills, and Reading Comprehension by Children with Reading Disabilities. Journal of Speech, Language, and Hearing Research Volume 50 Issue .4August 2007. Pages: 1093-1109.

37- Kate N. Joanne C. Dorothy V.M. Bishop (2010). A longitudinal investigation of early reading and language skills in children with poor reading comprehension. The Journal of Psychology and Psychiatry. Volume51, Issue9. Pages 1031-1039.

38- Lethbridge, A. (2016). The evolution of language and its Impact on Increase of the social Interaction of Learning Disabilities and phonological disabilities MSc. University of British Columbia.

39- Paul.R, Courtenay N., (2012). Language Disorders from Infancy Through Adolescence Listening, Speaking, Reading, Writing, and comminuting fourth Edition. Julie Eddy.london.UK

40- PotockiA.Jean E. \&Annie M.(2012). Narrative Comprehension Skills in 5-Year-Old Children: Correlational Analysis and Comprehender Profiles .The Journal of Educational Research . Volume 106, 2013 - Issue 1.

41- Sternberg.R(2018). Perspectives on Learning Disabilities Biological, Cognitive, Contextual. NewYork.doi.org/10.4324/9780429498381.

42- Taylor, R., Boca Raton, B., Smiley, \& Richard, S. (2009). Exceptional student: Preparing teacher for $21^{\text {st }}$ century. New York Mc Graw Hill. 